Article

\title{
Phytophthora austrocedri in Argentina and Co-Inhabiting Phytophthoras: Roles of Anthropogenic and Abiotic Factors in Species Distribution and Diversity
}

\author{
María Laura Vélez ${ }^{1,+}+\left(\mathbb{D}\right.$, Ludmila La Manna ${ }^{2,+}+\mathbb{C}$, Manuela Tarabini ${ }^{2}$, Federico Gomez ${ }^{2,3}$, \\ Matt Elliott ${ }^{4, \ddagger}$, Pete E. Hedley ${ }^{5}$, Peter Cock ${ }^{6}(\mathbb{D})$ and Alina Greslebin ${ }^{7, *, t}$ \\ 1 Centro de Investigación y Extensión Forestal Andino Patagónico (CIEFAP)—Consejo Nacional de \\ Investigaciones Científicas y Técnicas (CONICET), Universidad Nacional de la Patagonia (UNPSJB), \\ Ruta 259 Km 16,24, 9200 Esquel, Argentina; mvelez@ciefap.org.ar \\ 2 Centro de Estudios Ambientales Integrados, Facultad de Ingeniería, Universidad Nacional de la Patagonia \\ San Juan Bosco (UNPSJB)—Consejo Nacional de Investigaciones Científicas y Técnicas (CONICET), \\ Ruta 259 Km 16,4, 9200 Esquel, Argentina; llamanna@unpata.edu.ar (L.L.M.); \\ manuela.tarabini@yahoo.com.ar (M.T.); gomez.federico@inta.gob.ar (F.G.) \\ 3 Instituto Nacional de Tecnología Agropecuaria (INTA), 9200 Esquel, Argentina \\ 4 Forest Research, Roslin, Midlothian EH25 9SY, UK; MattElliot@woodlandtrust.org.uk \\ 5 Cell and Molecular Sciences, The James Hutton Institute, Invergowrie, Dundee DD2 5DA, UK; \\ Pete.Hedley@hutton.ac.uk \\ 6 Information and Computational Sciences, The James Hutton Institute, Invergowrie, Dundee DD2 5DA, UK; \\ Peter.Cock@hutton.ac.uk \\ 7 Centro de Investigación Esquel de Montaña y Estepa Patagónica (CONICET-UNPSJB)—Consejo Nacional de \\ Investigaciones Científicas y Técnicas (CONICET), Facultad de Ciencias Naturales y Cs. de la Salud, \\ Universidad Nacional de la Patagonia (UNPSJB), Ruta 259 Km 16,4, 9200 Esquel, Argentina \\ * Correspondence: agreslebin@unpata.edu.ar \\ + These authors equally contributed to the manuscript. \\ $\ddagger \quad$ The author now is at: The Woodland Trust, Edinburgh EH2 4PG, UK.
}

Received: 30 September 2020; Accepted: 16 November 2020; Published: 20 November 2020

check for updates

\begin{abstract}
This work reports the first survey of Phytophthora diversity in the forests soils of Andean Patagonia. It also discusses the role of anthropogenic impact on Phytophthora distribution inferred from the findings on Phytophthora diversity and on the distribution of Phytophthora austrocedri-diseased forests. Invasive pathogen species threatening ecosystems and human activities contribute to their entry and spread. Information on pathogens already established, and early detection of potential invasive ones, are crucial to disease management and prevention. Phytophthora austrocedri causes the most damaging forest disease in Patagonia, affecting the endemic species Austrocedrus chilensis (D. Don) Pic. Sern. and Bizzarri. However, the relationship between anthropogenic impacts and the disease distribution has not been analyzed enough. The aims of this work were: to evaluate Phytophthora diversity in soils of Andean Patagonia using a metabarcoding method, and analyze this information in relation to soil type and land use; to assess the distribution of Austrocedrus disease over time in relation to anthropogenic and abiotic gradients in an area of interest; and to discuss the role of human activities in Phytophthora spread. High throughput Illumina sequencing was used to detect Phytophthora DNA in soil samples. The distribution of Austrocedrus disease over time was assessed by satellite imagery interpretation. Twenty-three Phytophthora species, 12 of which were new records for Argentina, were detected. The most abundant species was $P$. austrocedri, followed by $P$. $\times$ cambivora, P. ramorum and P. kernoviae. The most frequent was P. $\times$ cambivora, followed by P. austrocedri and P. ramorum. Phytophthora richness and abundance, and Austrocedrus disease distribution, were influenced by land use, anthropogenic impact and soil drainage. Results showed several Phytophthoras, including
\end{abstract}


well-known pathogenic species. The threat they could present to Patagonian ecosystems and their relations to human activities are discussed. This study evidenced the need of management measures to control the spread of P. austrocedri and other invasive Phytophthora species in Patagonia.

Keywords: forest diseases; invasive species; metabarcoding; risk models

\section{Introduction}

Austrocedrus chilensis (D. Don) Pic. Sern. and Bizzarri (Patagonian Cypress) is a Cupressaceae endemic from the Patagonian Andean forests, distributed in the Andes and its piedmont of southern Argentina and Chile. Among the few gymnosperms inhabiting southern Argentina, it is the largest in surface area, covering ca. 140,000 ha [1]. It is considered a foundational species, able to define ecosystemic processes [2]. Cypress's importance lies not only in its high-quality wood, with straight stems used for construction and woodworking, but also in its environmental and landscape roles, as its forests surround cities and villages in the area.

Phytophthora austrocedri Gresl. and E. M. Hansen (Pythiales, Peronosporomycetes, Straminipila) has been identified as the primary pathogen causing the disease known as "Mal del ciprés" in Patagonian Andes forests [3], which causes mortality of $A$. chilensis. This disease was first documented in the 1940s as leading to stand-level mortality of $A$. chilensis on an island located in Nahuel Huapi lake, Argentina [4]. Nowadays, the disease is present in many places throughout the natural range of A. chilensis distribution in Argentina and in some parts of Chile.

The first characterizations of symptomatology described it as "foliage withering followed by progressive defoliation that, ultimately, leads to tree death" [4]. However, tree death can also occur rapidly, in which case the foliage changes from chlorotic to red [3,5]. The below-ground symptoms include root necrosis, which may affect the entire root system and extend through the root collar to the base of the stem. Rots are sometimes observed in roots and stem sapwood [6]. Descriptions of the disease assumed that symptoms originate in the root system and the death of the root tissues precedes crown symptoms [4,5,7]. Phytophthora austrocedri is the only pathogen that has been proven to cause the symptoms of the disease and cypress death, fulfilling Koch's postulates [3]. Another biological agent associated with Cypress death is the aphid Cinara cupressi (Buckton), but in this case, no root symptoms were reported [8,9], and dead crowns with still healthy roots were observed [10].

The main external symptoms of "Mal del ciprés", i.e., chlorosis and defoliation, are nonspecific symptoms that could lead to confusion about the origin of the disease. This uncertainty has given rise to debates on the primary and secondary roles of P. austrocedri in the disease. Alternatively, cavitation [11] and climate variation [11,12] have been hypothesized as alternative causes of death, considering that P. austrocedri acts as a secondary agent. However, the outbreak of the disease caused by P. austrocedri affecting Juniperus communis L. in the UK has confirmed the aggressiveness of this pathogen [13].

Amoroso et al. [14] showed that the mortality of individual trees was significantly associated with summer moisture, which agrees with the low tolerance to drought of trees with reduced root systems. These authors proposed that Mal del Ciprés is a decline process driven by complex interactions between abiotic and biotic factors that predispose (site conditions, genetic variation, sex of trees), incite (climatic variability, pathogen), and contribute (climatic variability, pathogen) to stand-level decline. We agree with this concept: forest diseases are the results of complex interactions between the pathogen, the host, and environmental conditions. Phytophthora's aggressiveness and development are highly related to site condition and individual host susceptibility [15-17]. In our opinion, the disease called "Mal del Ciprés" is actually a complex of symptoms of different origins, which includes those caused by P. austrocedri, C. cupressi, and climate-related stress. For this reason, hereafter, we use the name "Austrocedrus disease" to refer to the disease caused by P. austrocedri, which necessarily includes 
root death; and "Mal del Ciprés" to refer to the complex of different symptoms, decline, and mortalities observed in A. chilensis.

Phytophthora austrocedri was recorded for the first time in Patagonia (Argentina) attacking A. chilensis. Nowadays, the species has been recorded in other parts of the world, in all cases associated with plant species in the Cupressaceae family $[13,18,19]$. The susceptibility of other endemic Cupressaceae species (Fitzroya cupressoides (Molina) I.M. Johnst. and Pilgerodendron uviferum (D. Don.) Florín) has been demonstrated in vitro [20]. The species resides in clade 8 of the Phytophthora phylogenetic tree, which includes other important forest pathogens, such as P. ramorum Werres, De Cock and Man and P. lateralis Tucker and Milbrath [21,22]. Phylogenetic analysis of the nuclear and mitochondrial genes has shown that P. syringae (Kleb.) Kleb. and P. obscura Grünwald and Werres are their closest relatives [21-23]. It is a homothallic species, characterized by the combination of very slow growth, semi-papillate, non-caducous, and non-proliferating sporangia, oogonia with amphigynous antheridia, and a low $\left(15-17.5^{\circ} \mathrm{C}\right)$ optimal temperature for growth [7].

The geographic origin of P. austrocedri is unknown, but it is assumed to have been introduced into Argentina. The low genetic diversity, the lack of genetic heterogeneity between geographically distant populations, and the high impact of the pathogen on Patagonian forests support this hypothesis [24]. The species has also been introduced in the UK, where populations are genetically identical [13,19], but British and Argentinian isolates are two distinct clonal lineages that came from the same source population, whose location is still unknown [19].

The pathogen invades and kills the roots and extends from the dead roots to the stem as long necrotic lesions in the inner bark. Necrosis initiates in the cambial zone and affects the entire thickness of the phloem and the last rings of xylem $[25,26]$. Lesions may become inactive, but it is not known whether it happens due to the action of tree defenses, environmental conditions, or intrinsic conditions of the pathogen itself. Olate et al. [27] reported that the resin of infected trees showed relevant differences in its diterpene profiles in comparison with resin from healthy trees, and inhibition of mycelial growth in agar plates. Further studies are needed to disentangle the relative importance of the traumatic resins in the defense system of $A$. chilensis and its effectiveness against $P$. austrocedri. However, resin flux has also been observed in very active lesions, showing that the pathogen can overcome this defense [3].

A study monitoring physiological parameters of A. chilensis saplings after infection of P. austrocedri [25] showed that net photosynthesis (A), stomatal conductance (gs), and stem-specific hydraulic conductivity (Ks) decline after infection. Photosynthesis is altered before other parameters, when the necrotic lesion in the stem is still incipient and leaf tissue appears asymptomatic. The authors speculated that the effectors secreted by the pathogen may trigger an hypersensitive reaction -like reaction that leads to dysfunction in photosynthesis. All other physiological parameters decrease as the lesion develops. Abundant hyphae in tracheids and rays, and necrosis of xylem ray, can be observed in the xylem below the lesion. It was also found that tracheids of the xylem of affected adult trees show large numbers of trabeculae with different forms and in different arrangements, which are absent in healthy tissues near the lesion [28].

The systemic fungicides potassium phosphite, fosetyl-Al, and metalaxyl have been proven to effectively control P. austrocedri in planta, especially when administered preventively [29]. A remarkable aspect of these systemic fungicides is that the response of plant tissues to the toxins/effectors produced by P. austrocedri can be improved by them. Silva et al. [29] demonstrated that leaves pretreated with fosetyl-Al and metalaxyl are more resistant to the toxins/effectors of the pathogen than untreated controls, suggesting that these fungicides provide some resistance to the plant besides their direct fungistatic action on the pathogen.

Some species in the rhizosphere microbiota of $A$. chilensis trees have the potential to be used in biocontrol strategies against Austrocedrus disease. Some isolates in the genera Rhizobium and Delftia and some isolates of the species Penicillium glabrum (Wehmer) Westling and Penicillium lanosum Westling showed a fungistatic effect by decreasing $P$. austrocedri growth in vitro. However, certain bacterial isolates in the genera Bacillus and Pseudochrobactrum and some fungal isolates of species such as 
Penicillium corylophilum Dierckx, Penicillium palitans Westling, Penicillium fuscum (Sopp) Raper and Thom, and Trichoderma viridescens (A.S. Horne and H.S. Will.) Jaklitsch and Samuels had fungicidal effects, degrading P. austrocedri hyphae [30]. Moreover, bacterial isolates in the genera Delftia and Pseudochrobactrum slowed the progression of necrotic lesions when administered as a preventive treatment in P. austrocedri-inoculated plants [30].

An integrated strategy should also consider abiotic features, since they seem to play a main role in the disease onset and progression. Studies about the distribution and risk of Austrocedrus disease show that it is associated with wet soils, agreeing with studies at the stand level [31,32]. Austrocedrus chilensis stands are more prone to develop symptoms when occurring at sites with high precipitation, low elevations, gentle slopes, and fine-textured soils [33,34]. Thus, the habitat association approach allowed the authors to model the potential distribution of Austrocedrus disease [35,36]. Many studies have shown an association between Phytophthora attacks and wet soils [15,37-39]. The distance to streams was also found to be a key variable for evaluating Austrocedrus disease risk [35,36], in keeping with studies on forests affected by Phytophthora species around the world, which found that Phytophthora spreads along watercourses [38]. Studies on P. austrocedri outside Patagonia, affecting Juniperus communis woodlands in the UK, found that P. austrocedri DNA was consistently detected in soil samples [40] and that the affected area increased with waterlogging and soil moisture [17]. It was concluded that, once established at a site, P. austrocedri can be spread readily in soil locally via water run-off, and vectored by animal movements and human activities [40].

Phytophthora austrocedri is the first Phytophthora species reported as a pathogen of forest trees in Patagonia, but there has been no extensive search for other Phytophthora species in these soils. Previous studies have reported the presence of other Phytophthora species in P. austrocedri-infected A. chilensis forests in Patagonia, including P. $\times$ cambivora (Petri) Buisman, P. chlamydospora Brasier and E.M. Hansen, P. gonapodyides (H.E. Petersen) Buisman, P. syringae, P. cactorum (Lebert and Cohn) J. Schröt., P. taxon raspberry, and P. pseudotsugae Hamm and E.M. Hansen [41,42]. These studies reported the species isolated by baiting soil and watercourses. However, molecular methods, such as high throughput metabarcode sequencing, have been demonstrated to be more powerful tools to examine the diversity of Phytophthora species than classical baiting in environmental soil samples [43,44].

Disturbed sites may act as reservoirs from which invasive Phytophthora pathogens, particularly adapted to surviving in soil, can invade pathogen-free regions. Early detection of invasive Phytophthora species that can cause outbreaks in forests and ecosystems of Patagonia is of great importance to prevent invasions. Forest management needs scientific information to make decisions. The information previously presented, provided by several studies on P. austrocedri and Austrocedrus diseases that have been done in Argentina, has not been jointly analyzed. The aims of this work were: (a) to report the results of the first survey of Phytophthora diversity in forest soils of Andean Patagonia using a metabarcoding method, and to analyze this information in relation to the soil type and the land use; (b) to assess the distribution of Austrocedrus disease over time in relation to anthropogenic and abiotic factors in an area of interest; (c) finally, to discuss the roles of anthropogenic impacts given what could be inferred from all the information previously produced and the new information presented here.

\section{Materials and Methods}

\subsection{Assessment of Phytophthora Diversity in Soils}

The sampling area covered a range of $200 \mathrm{~km}$ from the northernmost to the southernmost point in a narrow strip of up to $30 \mathrm{~km}$ in width (Figure 1). Fifteen sites were visited in this area. Sampling sites included protected areas and areas with medium and high anthropogenic impact interventions, including farming and cattle raising, forestry, and rural urbanization (Table 1). Sampling sites were numbered correlatively from north to south. Soil samples were taken from 30 to $35 \mathrm{~cm}$ depth, after removing the top 3-5 cm of soil, and collected in a plastic bag, transported, and stored in cool conditions until processing (no longer than 2 days). 


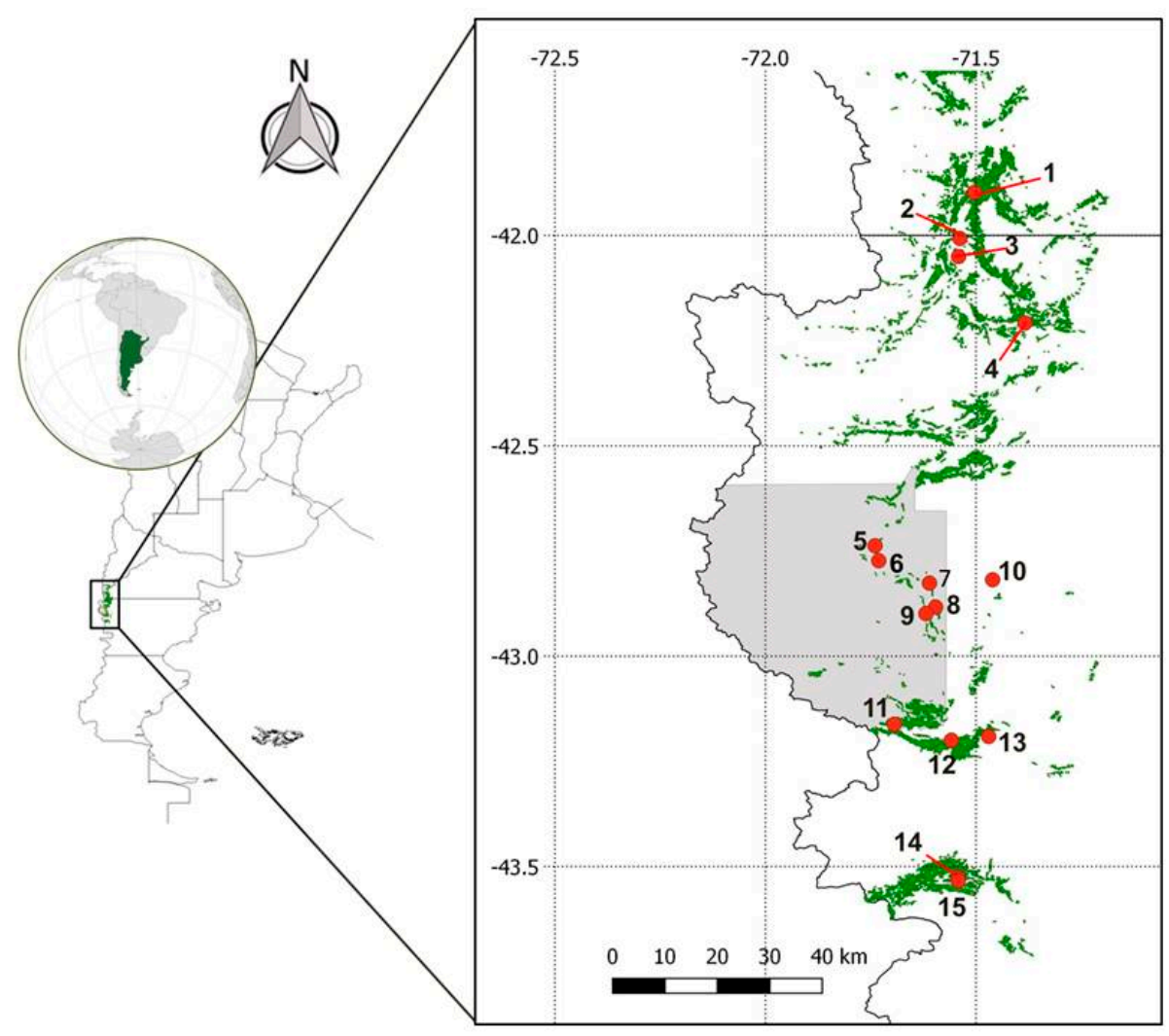

Figure 1. Distribution of Austrocedrus chilensis (D. Don) Pic. Sern. and Bizzarri forests in Río Negro and Chubut provinces, Argentina (source: Forest Inventory, report by CIEFAP, 2016) and location of sampling sites of the Phytophthora diversity study. Sampling site 11 coincides with the study area of Austrocedrus disease distribution over time. The sector shaded in gray corresponds to the protected area Los Alerces National Park.

DNA extraction from soil was performed according to Riddell et al. [44]. Briefly, each soil sample was oven-dried at $\approx 60{ }^{\circ} \mathrm{C}$ in aluminum trays for 1-3 day(s) (depending on soil wetness), stirred thoroughly once dry, and had DNA extracted from three $250 \mathrm{mg}$ subsamples using the PowerSoil ${ }^{\circledR}$ DNA Isolation Kit (MoBio Laboratories Inc., Carlsbad, CA, USA). A robotic workstation for DNA extraction based on magnetic particle purification (Kingfisher ${ }^{\mathrm{TM}} \mathrm{mL}$ Magnetic Particle Processor, Thermo Scientific, Loughborough, UK) was used for the DNA extraction process. DNA extracts were further purified using either the Jet-QuickTM DNA Purification Kit (Genomed GmbH, Löhne, Germany) or DNA Clean and Concentrator ${ }^{\mathrm{TM}}$ (Zymo Research Corp., Irvine, CA, USA) according to the manufacturer's instructions.

\subsection{Metabarcoding Analysis}

Genomic DNA of positive controls was extracted from mycelium harvested from each of the Phytophthora cultures on V8 agar using the Nucleospin Plant Prep II kit (Machery-Nagel, Düren, Germany) according to the manufacturer's instructions. Quantitative real-time PCR was carried out on an ABI Prism 7300 Real Time PCR System (Applied Biosystems, Foster City, CA, USA) with the primers 18Ph2F and 5.8S-1R [24] using different dilutions of DNA of each Phytophthora species (5, 10, $25,50,100$, and 500X). Cycle threshold (Ct) values at each concentration were determined, and DNAs from each species corresponding to $\mathrm{Ct}$ values between 22 and 30 were pooled for the DNA control mix; thus, species were not expected to be present in equal abundance [44]. 
Table 1. Description of sampling sites: localization and descriptions of the vegetation, geomorphology, and land use.

\begin{tabular}{|c|c|c|c|c|c|c|}
\hline & Site & Samples & Coordinates & Type of Vegetation & $\begin{array}{l}\text { Geomorphology and } \\
\text { Soil Drainage }\end{array}$ & Land Use/Anthropic Impacts \\
\hline 1 & $\begin{array}{l}\text { Rio Negro province, Road } \\
40 \text { way out El Bolsón }\end{array}$ & $49-50$ & $\begin{array}{l}41^{\circ} 53^{\prime} 50.3^{\prime \prime} \mathrm{S} \\
71^{\circ} 30^{\prime} 12.4^{\prime \prime} \mathrm{W}\end{array}$ & $\begin{array}{c}\text { Crops, grass, and exotic } \\
\text { ornamentals. Native forest } \\
\text { dominated by } \\
\text { Austrocedrus chilensis nearby. }\end{array}$ & $\begin{array}{l}\text { Valley. } \\
\text { Moderately well- to } \\
\text { poorly-drained soils. }\end{array}$ & $\begin{array}{l}\text { Cattle raising, farming, forestry, } \\
\text { buildings. Highly anthropized area. } \\
\text { Sampled near to the road. Austrocedrus } \\
\text { disease in the nearby forests. }\end{array}$ \\
\hline 2 & $\begin{array}{l}\text { Río Negro, Golondrinas, } \\
\text { Instituto Nacional de } \\
\text { Tecnología Agropecuaria } \\
\text { (INTA), Forest Reserve }\end{array}$ & $47-48$ & $\begin{array}{l}42^{\circ} 00^{\prime} 25.7^{\prime \prime} \mathrm{S} \\
71^{\circ} 32^{\prime} 17.3^{\prime \prime} \mathrm{W} \\
42^{\circ} 00^{\prime} 23.4^{\prime \prime} \mathrm{S} \\
71^{\circ} 32^{\prime} 17.4^{\prime \prime} \mathrm{W}\end{array}$ & $\begin{array}{l}\text { Mixed native forest dominated } \\
\text { by } A \text {. chilensis. }\end{array}$ & $\begin{array}{l}\text { Valley. } \\
\text { Well to moderately } \\
\text { well-drained soils. }\end{array}$ & $\begin{array}{l}\text { Austrocedrus disease. Historic forestry } \\
\text { and grazing. Nowadays is a forest } \\
\text { reserve with recreational use. }\end{array}$ \\
\hline 3 & $\begin{array}{l}\text { Chubut, El Hoyo, Burned } \\
\text { area near road } 40\end{array}$ & $\begin{array}{c}46 \\
51-52\end{array}$ & $\begin{array}{l}42^{\circ} 03^{\prime} 28.9^{\prime \prime} \mathrm{S} \\
71^{\circ} 32^{\prime} 09.1^{\prime \prime} \mathrm{W} \\
42^{\circ} 03^{\prime} 00.2^{\prime \prime} \mathrm{S} \\
71^{\circ} 32^{\prime} 28.1^{\prime \prime} \mathrm{W}\end{array}$ & $\begin{array}{l}\text { Burned conifer plantations and } \\
\text { mixed native forest dominated } \\
\text { by A. chilensis. }\end{array}$ & $\begin{array}{l}\text { Valley. } \\
\text { Well to poorly } \\
\text { drained soils. }\end{array}$ & $\begin{array}{l}\text { Grazing, exotic tree plantations. } \\
\text { Farming nearby. Austrocedrus disease } \\
\text { in the nearby forests. }\end{array}$ \\
\hline 4 & $\begin{array}{l}\text { Chubut, Route } 40 \text { at the } \\
\text { junction of route to } \\
\text { El Maitén }\end{array}$ & $44-45$ & $\begin{array}{l}42^{\circ} 12^{\prime} 28.8^{\prime \prime} \mathrm{S} \\
71^{\circ} 23^{\prime} 00.2^{\prime \prime} \mathrm{W}\end{array}$ & $\begin{array}{l}\text { Mixed native forest dominated } \\
\text { by } A \text {. chilensis. }\end{array}$ & $\begin{array}{l}\text { Valley. } \\
\text { Well to poorly } \\
\text { drained soils. }\end{array}$ & $\begin{array}{l}\text { Austrocedrus disease, } \\
\text { road construction. }\end{array}$ \\
\hline 5 & $\begin{array}{l}\text { Los Alerces National Park, } \\
\text { River Arrayanes }\end{array}$ & $21-22$ & $\begin{array}{c}42^{\circ} 44^{\prime} 15.5^{\prime \prime} \mathrm{S} \\
071^{\circ} 44^{\prime} 22.8^{\prime \prime} \mathrm{W}\end{array}$ & $\begin{array}{l}\text { Nothofagus dombeyi } \\
\text { dominated forests }\end{array}$ & $\begin{array}{c}\text { Slopes. } \\
\text { Well-drained soils. }\end{array}$ & $\begin{array}{l}\text { Touristic and recreational use. } \\
\text { Some grazing. }\end{array}$ \\
\hline 6 & $\begin{array}{l}\text { Los Alerces National Park, } \\
\text { Braese, Road } 71\end{array}$ & $17-20$ & $\begin{array}{l}42^{\circ} 46^{\prime} 23.4^{\prime \prime} \mathrm{S} \\
71^{\circ} 43^{\prime} 50.8^{\prime \prime} \mathrm{W}\end{array}$ & $\begin{array}{l}\text { Mixed forest of } N \text {. dombeyi and } \\
\text { A. chilensis }\end{array}$ & $\begin{array}{c}\text { Slopes. } \\
\text { Well-drained soils. }\end{array}$ & $\begin{array}{l}\text { Touristic and recreational use. } \\
\text { Some grazing. Austrocedrus disease. }\end{array}$ \\
\hline 7 & $\begin{array}{l}\text { Los Alerces National Park, } \\
\text { Pucon Pai }\end{array}$ & $23-25$ & $\begin{array}{l}42^{\circ} 49^{\prime} 35.3^{\prime \prime} \mathrm{S} \\
71^{\circ} 36^{\prime} 37.4^{\prime \prime} \mathrm{W}\end{array}$ & $\begin{array}{l}\text { Mixed forest dominated by } \\
\text { A. chilensis }\end{array}$ & $\begin{array}{c}\text { Slopes. } \\
\text { Well-drained soils. }\end{array}$ & $\begin{array}{l}\text { Intense touristic and recreational use. } \\
\text { Some grazing. Austrocedrus disease. }\end{array}$ \\
\hline 8 & $\begin{array}{l}\text { Los Alerces } \\
\text { National Park, cabecera }\end{array}$ & $26-27$ & $\begin{array}{l}42^{\circ} 53^{\prime} 00.3^{\prime \prime} \mathrm{S}, \\
71^{\circ} 35^{\prime} 44.7^{\prime \prime} \mathrm{W}\end{array}$ & $\begin{array}{l}\text { Mixed forest dominated by } \\
\text { A. chilensis }\end{array}$ & $\begin{array}{l}\text { Slopes. } \\
\text { Well-drained soils. }\end{array}$ & $\begin{array}{l}\text { Touristic area, one of the most visited } \\
\text { area of the national park, } \\
\text { some grazing, Austrocedrus disease. }\end{array}$ \\
\hline 9 & $\begin{array}{l}\text { Los Alerces National Park, } \\
\text { burned area. }\end{array}$ & $13-16$ & $\begin{array}{l}42^{\circ} 53^{\prime} 56.21^{\prime \prime} \mathrm{S} \\
71^{\circ} 37^{\prime} 8.08^{\prime \prime} \mathrm{W}\end{array}$ & $\begin{array}{l}\text { Burned area of native mixed } \\
\text { forests dominated by } \\
\text { A. chilensis. }\end{array}$ & $\begin{array}{l}\text { Slopes. } \\
\text { Well-drained soils. }\end{array}$ & $\begin{array}{l}\text { Forest fire (10 years before), } \\
\text { some grazing. }\end{array}$ \\
\hline 10 & $\begin{array}{l}\text { Chubut, Futaleufú, } \\
\text { Huemules }\end{array}$ & $\begin{array}{c}28 \\
29-30 \\
31-32 \\
33\end{array}$ & $\begin{array}{c}42^{\circ} 47^{\prime} 59.7^{\prime \prime} \mathrm{S}, \\
71^{\circ} 27^{\prime} 23.8^{\prime \prime} \mathrm{W} \\
42^{\circ} 48^{\prime} 23.3^{\prime \prime} \mathrm{S}, \\
71^{\circ} 27^{\prime} 34.8^{\prime \prime} \mathrm{W} \\
42^{\circ} 49^{\prime} 06.6^{\prime \prime} \mathrm{S} \\
71^{\circ} 27^{\prime} 37.3^{\prime \prime} \mathrm{W} \\
42^{\circ} 49^{\prime} 33.2^{\prime \prime} \mathrm{S}, \\
71^{\circ} 27^{\prime} 29.9^{\prime \prime} \mathrm{W}\end{array}$ & $\begin{array}{l}\text { Native forest of } \\
\text { Nothofagus pumilio. }\end{array}$ & $\begin{array}{l}\text { Slopes. } \\
\text { Well-drained soils. }\end{array}$ & Cattle raising and forestry. \\
\hline
\end{tabular}


Table 1. Cont

\begin{tabular}{|c|c|c|c|c|c|c|}
\hline & Site & Samples & Coordinates & Type of Vegetation & $\begin{array}{l}\text { Geomorphology and } \\
\text { Soil Drainage }\end{array}$ & Land Use/Anthropic Impacts \\
\hline 11 & $\begin{array}{l}\text { Los Alerces National Park, } \\
\text { ranch Burgos }\end{array}$ & $53-54$ & $\begin{array}{c}43^{\circ} 9^{\prime} 38.00^{\prime \prime} \mathrm{S}, \\
71^{\circ} 42^{\prime} 54.00^{\prime \prime} \mathrm{W} \\
43^{\circ} 9^{\prime} 46.26^{\prime \prime} \mathrm{S}, \\
71^{\circ} 41^{\prime} 38.99^{\prime \prime} \mathrm{W}\end{array}$ & A. chilensis dominated forests. & $\begin{array}{l}\text { Valley. } \\
\text { Moderately well- to } \\
\text { poorly- drained soils. }\end{array}$ & $\begin{array}{l}\text { Cattle raising and forestry (area with } \\
\text { private use inside the national park). } \\
\text { Austrocedrus disease. }\end{array}$ \\
\hline 12 & $\begin{array}{l}\text { Chubut, Trevelin, } \\
\text { Ranch "La 106" }\end{array}$ & $1-6$ & $\begin{array}{l}43^{\circ} 11^{\prime} 59.7^{\prime \prime} \mathrm{S} \\
71^{\circ} 33^{\prime} 30.1^{\prime \prime} \mathrm{W}\end{array}$ & $\begin{array}{l}\text { Austrocedrus chilensis } \\
\text { dominated forests. }\end{array}$ & $\begin{array}{l}\text { Plains and hill slopes. } \\
\text { Moderately well- to very } \\
\text { poorly-drained soils. }\end{array}$ & $\begin{array}{l}\text { Cattle raising, forestry and forest } \\
\text { plantations, Austrocedrus disease. }\end{array}$ \\
\hline 13 & $\begin{array}{l}\text { Reserve Nant y Falls } \\
\text { cascades }\end{array}$ & $7-12$ & $\begin{array}{l}43^{\circ} 11^{\prime} 28^{\prime \prime} \mathrm{S} \\
71^{\circ} 28^{\prime} 11^{\prime \prime} \mathrm{W}\end{array}$ & $\begin{array}{l}\text { Austrocedrus chilensis } \\
\text { dominated forests. }\end{array}$ & $\begin{array}{l}\text { Plains and hill slopes. } \\
\text { Moderately well- to very } \\
\text { poorly-drained soils. }\end{array}$ & $\begin{array}{l}\text { Austrocedrus disease, cattle raising and } \\
\text { historic forestry. Nowadays forests } \\
\text { are protected. }\end{array}$ \\
\hline 14 & Corcovado Ruta 17 & $\begin{array}{l}40-41 \\
42-43\end{array}$ & $\begin{array}{c}43^{\circ} 31^{\prime} 32.3^{\prime \prime} \mathrm{S}, \\
71^{\circ} 32^{\prime} 30.8^{\prime \prime} \mathrm{W} \\
43^{\circ} 31^{\prime} 37.7^{\prime \prime} \mathrm{S}, \\
71^{\circ} 32^{\prime} 32.1^{\prime \prime} \mathrm{W}\end{array}$ & $\begin{array}{l}\text { Austrocedrus chilensis } \\
\text { dominated forests with areas of } \\
\text { mallín (wet land). }\end{array}$ & $\begin{array}{l}\text { Valley. } \\
\text { Somewhat poorly- } \\
\text { drained to poorly- } \\
\text { drained soils. }\end{array}$ & $\begin{array}{l}\text { Cattle raising, some forestry, } \\
\text { and Austrocedrus disease. }\end{array}$ \\
\hline 15 & $\begin{array}{l}\text { Chubut, Corcovado, } \\
\text { Santa Teresita Ranch }\end{array}$ & $\begin{array}{c}34 \\
35 \\
36-37 \\
38-39\end{array}$ & $\begin{array}{c}43^{\circ} 32^{\prime} 05.2^{\prime \prime} \mathrm{S}, \\
71^{\circ} 33^{\prime} 04.5^{\prime \prime} \mathrm{W} \\
43^{\circ} 32^{\prime} 00.1^{\prime \prime} \mathrm{S}, \\
71^{\circ} 32^{\prime} 28.1^{\prime \prime} \mathrm{W} \\
43^{\circ} 32^{\prime} 01.9^{\prime \prime} \mathrm{S}, \\
71^{\circ} 32^{\prime} 30.7^{\prime \prime} \mathrm{W} \\
43^{\circ} 31^{\prime} 55.5^{\prime \prime} \mathrm{S}, \\
71^{\circ} 32^{\prime} 30.5^{\prime \prime} \mathrm{W}\end{array}$ & $\begin{array}{l}\text { Austrocedrus chilensis } \\
\text { dominated forests }\end{array}$ & $\begin{array}{l}\text { Valley. } \\
\text { Moderately well- to } \\
\text { poorly-drained soils. }\end{array}$ & Cattle raising, Austrocedrus disease \\
\hline
\end{tabular}


For metabarcoding analysis, an about $250 \mathrm{bp}$ ITS1 region was amplified from each DNA sample using nested-PCR with primer pairs 18Ph2F and 5.8S-1R in the first round and ITS6 and 5.8S-1R in the second round, according to the protocol of Scibetta et al. [45], except that proof-reading enzyme KAPA HiFi HotStart ReadyMix (KAPA Biosystems, Wilmington, MA, USA) was used for the PCR to minimize errors during PCR. Second round primers were amended with overhang adapters to ensure compatibility with the Illumina index and sequencing adapters. These were as follows: forward overhang: 5'TCGTCGGCAGCGTCAGATGTGTATAAGAGACAG- [ITS6] and reverse overhang: 5'GTCTCGTGGGCTCGGAGATGTGTATAAGAGACAG-[5.8S-1R] [46]. For each DNA sample, PCR was carried out in triplicate and all Phytophthora-positive PCR replicates were pooled for downstream processing.

Illumina sequencing library preparation and sequencing were performed following the protocols for 16S Metagenomic Sequencing Library Preparation [46] and methods described by Riddell et al. [44], and sequenced together with a negative control and the 10 Phytophthora species positive control mixes as part of the second 96-well plate in that work. The raw Illumina data are available for the NCBI SRA or ENA under accession PRJEB40677. Sequence data were initially processed with the same "metapy" pipeline, and repeated with version v0.6.9 of successor tool THAPBI PICT, giving broadly the same results. It performed quality trimming with Trimmomatic v0.39 [47], merged paired reads with Flash v1.2.11 [48], removed primers using cutadapt v2.8 [49], and collated unique sequences with a minimum sample abundance of 50 reads. The unique sequences were matched to species in the tool's curated Phytophthora ITS1 database using the default classifier, which requires perfect matches or at most a one base pair difference.

\subsection{Cluster Analysis of Phytophthora $\beta$-Diversity}

A cluster analysis was applied to compare and evaluate the similarity of species composition and abundance of Phytophthora spp. between sites. Analysis was applied twice: (a) using abundance data (number of Illumina reads) of each species in each site; (b) using presence/absence data of each species in each site.

For abundance data, three similarity indexes were tested: Euclidean distance, Bray-Curtis, and simple matching. For binary data, five indexes were tested: Euclidean distance, simple matching, dice, Sokal Sneath 1, and Sokal Sneath 2 . As a clustering method, three different algorithms were tested: single linkage, average linkage, and Ward. The combination of index and clustering method that provided the highest cophenetic correlation and the best clade resolution was chosen. For abundance data, the Bray-Curtis similarity index and Ward clustering method were used. For binary data, Euclidean distance and average linkage clustering method were used. Cluster analysis was conducted in Infostat [50].

\subsection{Assessment of the Disease Distribution over Time}

The current distribution of the diseased forest was evaluated in an area located in Los Alerces National Park, coinciding with site 11 of the Phytophthora diversity study (Figure 1; Figure S1A). The study area covers 900 ha of $A$. chilensis forests, for which maps of the disease distribution in 2005 and 2007 are available [51]. The forest that became diseased in the period 2007-2020 was visually identified using high-resolution satellite images from Bing maps (https://www.bing.com/maps/). Satellite imagery interpretation was performed visually by a human operator. The distribution of the affected forests (in 2005, 2007, and 2020) and the currently asymptomatic forests were analyzed considering as asymptomatic those forests that did not show external symptoms. The term asymptomatic was widely used for naming disease-free trees [29-31,34], since Austrocedrus disease symptoms may appear later in the crown [3].

In order to analyze the influences of anthropogenic factors on disease distribution, the spatial distribution of diseased forests over time was analyzed according to the distance to trails and to the distance to the Grande river, which represents an environmental and anthropical gradient. Raster layers 
of distances to trails and to Grande river with $10 \times 10 \mathrm{~m}$ resolution [51] were categorized. The areas of diseased forest over time (2005/2007/2020) and of currently asymptomatic forest (2020) corresponding to each distance category were assessed and histograms were built. In order to analyze the disease progression in the last period (2007-2020) in relation to the risk of being diseased according to abiotic factors [35], the risk was calculated for each polygon feature by Zonal statistics plugin. Analyses were performed with QGis software version 2.18.21 [52].

\section{Results}

\subsection{Phytophthora Diversity in Patagonian Forest Soils and P. austrocedri Distribution}

Of the 54 soil samples collected from the 15 sites, a total of 47 samples from 14 sites were found to contain Phytophthora DNA and were progressed to Illumina sequencing. These 47 samples yielded DNA sequences matching with a total of 23 known Phytophthora species (Table 2). P. austrocedri was positively detected in 39 of these samples. Almost $43 \%$ of reads corresponded to $P$. austrocedri, $15.8 \%$ to P. $\times$ cambivora, $7.8 \%$ to P. ramorum, and 7\% to P. kernoviae Brasier, Beales and S.A. Kirk. Other species were represented by $\leq 3 \%$ of the reads (Figure $2 \mathrm{~A}$ ). Additionally, $11.5 \%$ of the reads corresponded to unknown species in the oomycete genus (Figure 2A).
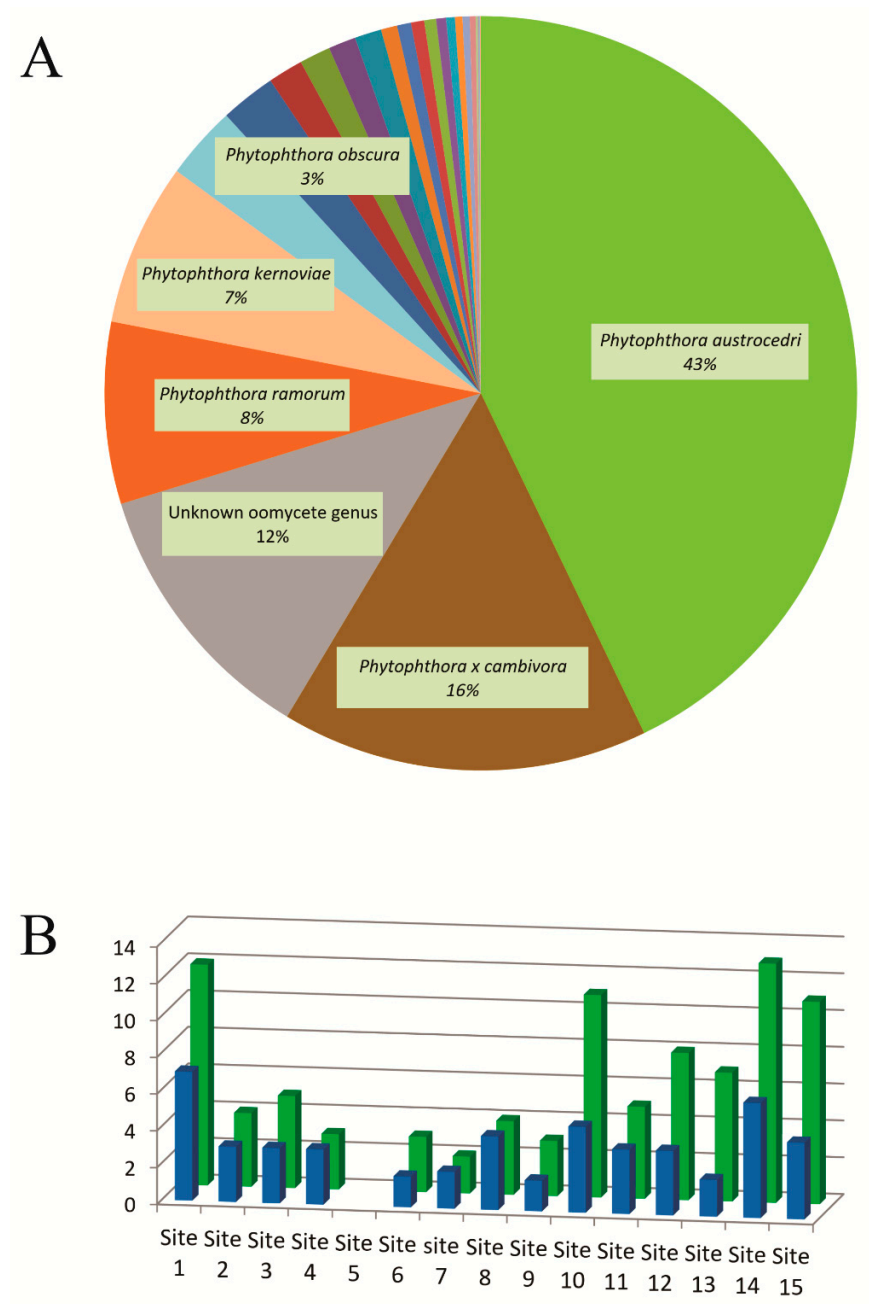

Figure 2. (A) Percentage of Illumina reads corresponding to each assigned species in soil samples from Patagonia. Only species with $\geq 3 \%$ of readings are labeled. (B) Mean richness per sample (blue bars) and total richness (green bars) of each site. No Phytophthora DNA was detected in site 5. 
Table 2. Read counts per site and assigned species. The number of samples varied from two to six per site (see Table 1).

\begin{tabular}{|c|c|c|c|c|c|c|c|c|c|c|c|c|c|c|c|}
\hline Species & Clade & Site 1 & Site 2 & Site 3 & Site 4 & Site 6 & Site 7 & Site 8 & Site 9 & Site 10 & Site 11 & Site 12 & Site 13 & Site 14 & Site 15 \\
\hline Phytophthora aleatoria P.M. Scott, R. L & & & & & & & & & & & & & & & \\
\hline $\begin{array}{l}\text { McDougal \& P.M Taylor } \\
\text { /cactorum (Lebert \& Cohn) J. Schröt. }\end{array}$ & 1 & 0 & 0 & 0 & 0 & 0 & 0 & 0 & 0 & 0 & 411 & 0 & 0 & 0 & 271 \\
\hline $\begin{array}{l}\text { P. idaei D.M. Kenn } \\
\text { P. }\end{array}$ & 1 & 92 & 0 & 0 & 0 & 0 & 0 & 0 & 0 & 0 & 0 & 0 & 0 & 0 & 0 \\
\hline $\begin{array}{l}\text { P. caryae N.J. Brazee, X. Yang \& C.X. } \\
\text { Hong/pini Leonian }\end{array}$ & 2 & 0 & 0 & 0 & 0 & 0 & 0 & 0 & 0 & 76 & 0 & 0 & 0 & 1889 & 536 \\
\hline P. plurivora T. Jung \& T.I. Burgess & 2 & 0 & 0 & 0 & 0 & 0 & 0 & 0 & 0 & 0 & 0 & 0 & 0 & 0 & 84 \\
\hline P. ilicis Buddenh. \& Roy A. Young & 3 & 0 & 0 & 162 & 0 & 0 & 0 & 0 & 0 & 0 & 0 & 198 & 0 & 287 & 4511 \\
\hline P. pseudosyringae T. Jung \& Delatour & 3 & 858 & 150 & 0 & 0 & 0 & 0 & 0 & 0 & 492 & 1632 & 0 & 0 & 0 & 127 \\
\hline $\begin{array}{l}\text { P. bilorbang Aghighi, G.E. Hardy, J.K. Scott \& } \\
\text { T.I. Burgess }\end{array}$ & 6 & 0 & 0 & 0 & 0 & 0 & 0 & 0 & 0 & 0 & 0 & 0 & 0 & 196 & 0 \\
\hline P. chlamydospora Brasier \& E.M. Hansen & 6 & 667 & 0 & 0 & 0 & 0 & 0 & 0 & 0 & 181 & 0 & 0 & 771 & 929 & 0 \\
\hline P. gonapodyides (H.E. Petersen) Buisman & 6 & 0 & 0 & 0 & 0 & 0 & 0 & 0 & 0 & 0 & 0 & 222 & 0 & 88 & 239 \\
\hline P. megasperma Drechsler & 6 & 0 & 0 & 0 & 0 & 0 & 0 & 0 & 0 & 581 & 0 & 0 & 0 & 524 & 0 \\
\hline $\begin{array}{l}\text { P. mississippiae Xiao Yang, Copes \& } \\
\text { C.X. Hong }\end{array}$ & 6 & 0 & 0 & 0 & 0 & 0 & 0 & 0 & 0 & 100 & 0 & 0 & 0 & 0 & 0 \\
\hline P. $\times$ cambivora (Petri) Buisman & 7 & 1687 & 776 & 2356 & 1169 & 3823 & 1896 & 1088 & 5337 & 1836 & 0 & 6450 & 4629 & 644 & 2453 \\
\hline P. cinnamomi Rands & 7 & 0 & 0 & 0 & 0 & 0 & 0 & 0 & 0 & 0 & 709 & 0 & 215 & 0 & 0 \\
\hline P. austrocedri Gresl. \& E. M. Hansen & 8 & 4517 & 3798 & 7143 & 3525 & 8398 & 0 & 3297 & 0 & 8268 & 10,375 & 6371 & 12,583 & 7118 & 17,447 \\
\hline P. cryptogea Pethybr. \& Laff./pseudocryptogea & & & & & & & & & & & & & & & \\
\hline $\begin{array}{l}\text { Safaiefarahani, Mostowfizadeh, } \\
\text { Hardy \& Burgess }\end{array}$ & 8 & 822 & 0 & 0 & 0 & 0 & 0 & 0 & 0 & 0 & 0 & 0 & 0 & 0 & 0 \\
\hline P. lateralis Tucker \& Milbrath & 8 & 0 & 0 & 0 & 0 & 0 & 0 & 0 & 393 & 0 & 0 & 0 & 0 & 279 & 0 \\
\hline P. obscura Grünwald \& Werres & 8 & 324 & 0 & 89 & 0 & 336 & 0 & 311 & 0 & 1859 & 0 & 701 & 1242 & 1504 & 458 \\
\hline P. primulae J.A. Toml. & 8 & 1505 & 0 & 0 & 0 & 0 & 0 & 0 & 0 & 0 & 0 & 0 & 0 & 0 & 0 \\
\hline $\begin{array}{l}\text { P. pseudocryptogea Safaiefarahani, } \\
\text { Mostowfizadeh, Hardy \& Burgess }\end{array}$ & 8 & 1305 & 0 & 0 & 0 & 0 & 0 & 0 & 0 & 0 & 0 & 0 & 0 & 0 & 0 \\
\hline P. ramorum Werres, De Cock \& Man & 8 & 2673 & 3752 & 692 & 527 & 0 & 0 & 962 & 0 & 5459 & 455 & 159 & 57 & 349 & 1408 \\
\hline P. syringae (Kleb.) Kleb. & 8 & 0 & 0 & 0 & 0 & 0 & 0 & 0 & 0 & 1952 & 0 & 343 & 0 & 600 & 0 \\
\hline P. kernoviae Brasier, Beales \& S.A. Kirk & 10 & 236 & 0 & 0 & 0 & 0 & 5450 & 0 & 474 & 2853 & 0 & 1818 & 1492 & 187 & 2605 \\
\hline Unknown oomycete genus & & 1603 & 594 & 55 & 0 & 2537 & 2442 & 0 & 451 & 3821 & 457 & 2043 & 3199 & 7827 & 3567 \\
\hline
\end{tabular}


Phytophthora species were detected in seven out of ten clades recognized by Yang et al. [22]. Fifty-seven percent of reads corresponded to species in clade $8 ; 16 \%$ to species in clade $7 ; 7 \%$ to species in clade 10; and $4 \%$ to species in clade 3 . Clades 1,2 , and 6 were represented in $2 \%$ or less of the reads, and species in clades 4, 5, and 9 were not detected (Figure $2 \mathrm{~A}$ ).

Among the 47 samples that were positive for Phytophthora, the mean number of distinct species detected per sample was $3.57 \pm 1.94$, with values ranging from one to ten species per sample (Figure 2B). A maximal number of species was detected in site 14 (located in the southernmost sampling area) with 13 species, followed by site 1 (located in the northernmost sampling area) with 12 species, and site 15 (located in the same sampling area as site 14) and site 10 (a Nothofagus pumilio (Poepp. and Endl.) Krasser forest in the central area of the sampling range), both of them with 11 species (Figure 2B).

The sites with the highest Phytophthora richness were usually those located in areas raising cattle and/or populated rural areas. On the contrary, protected areas showed low species richness. No Phytophthora species were detected in site 5, and of sites yielding Phytophthora DNA, the site with the lowest number of species (2) was site 7, both of them located in Los Alerces National Park. The mean richness of the five sites in this protected area (sites 6 to 9 and 11) was 3.4 species, while the mean richness in sites located in lands with different economic activities (agriculture, forestry, grazing, etc.) (sites 1, 10, 13, 14 and 15) was 10.8 (Table 2).

\subsection{Cluster Analysis of Phytophthora $\beta$-Diversity}

The similarity in species composition and abundance between sites was analyzed using cluster analysis (Figure 3A). No clear geographic structure was found; instead, it was observed that sites clustered more by land use, anthropogenic impact, or soil drainage, rather than by proximity. Sites inside the most protected of all sampled areas (Los Alerces National Park sites 69 and 11; Figure 1) clustered together (dark green), except for site 11, which, even though it is inside the national park, is subject to cattle raising and some forestry, and the soils are worse drained. In site 11 the study of Austrocedrus disease distribution over time was carried out. Three sites located towards the northern sampling area, distant from Los Alerces National Park (Figure 1), were grouped within the same clade (dark green). These sites were a native forest reserve (site 2), a native forest near a road (site 4), both of them with limited human activities, and a burned area that was formerly native forest and conifer plantations (site 3) with medium anthropogenic impact. The three sites had well-drained soils (Table 1).

Two other geographically close sites (12 and 13, Figure 1) formed a clade (orange) that grouped with the previous one. These two sites are pure $A$. chilensis forests developed on clayish plains and hillslopes, and the main anthropogenic impact is cattle raising. The nine sites previously mentioned were grouped together (pale green rectangle). The dark green clade includes those sites with low species richness, and the orange clade includes those sites with median species richness.

Site 11, which is in the same valley as sites 12 and 13, and site 15 which is distant from the last one, located in the southernmost area of $A$. chilensis distribution (Figure 1), grouped then with the previous clades (yellow rectangle). These sites correspond to Austrocedrus pure forest located at the bottom of a valley, on moderately well to poorly drained soils (Table 1). Both sites have cattle raising and are the only two sites where P. aleatoria/cactorum was recorded. Site 15 has also one unique species (P. plurivora), which explains its lowest similarity.

The last clade (pale blue), with lower similarity, grouped sites 10 and 14, two of the three sites with the highest species richness (11 and 13 species, respectively). These sites are very different from each other: site 10 is a N. pumilio pure forest, with well-drained soil, located far away from site 14, which is an Austrocedrus-dominated forest located on wet soil. Their similarity is that both share an otherwise unique species ( $P$. megasperma) and each of them also has a unique species ( $P$. mississippiae at site 10 , and P. bilorbang at site 14). The last site, with the lowest similarity, is site 1 which has five unique species (P. capensis/citricola, P. cryptogea/pseudocryptogea, P. idaei, P. primulae, P. pseudocryptogea). It could be said that sites $15,10,14$, and 1 , which show the highest species richness, have low similarity among them, mostly because of the presence of unique species. The cophenetic correlation was 0.97 . 
A

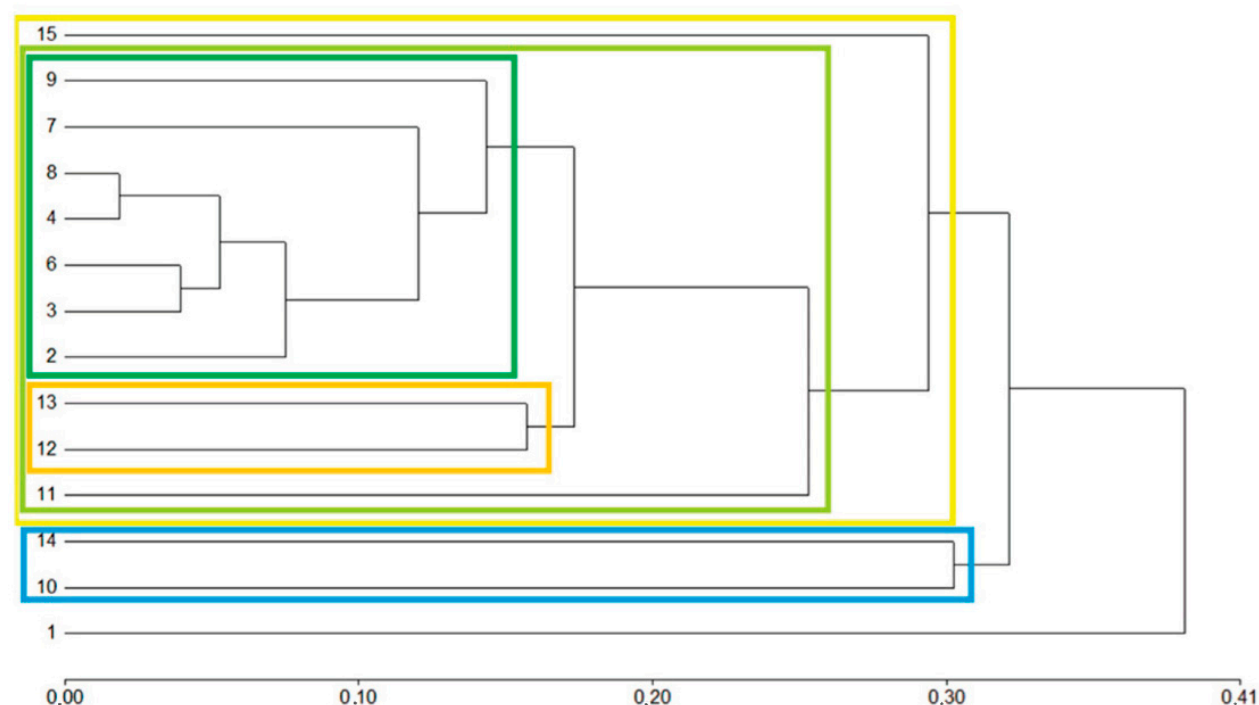

$\mathrm{B}$

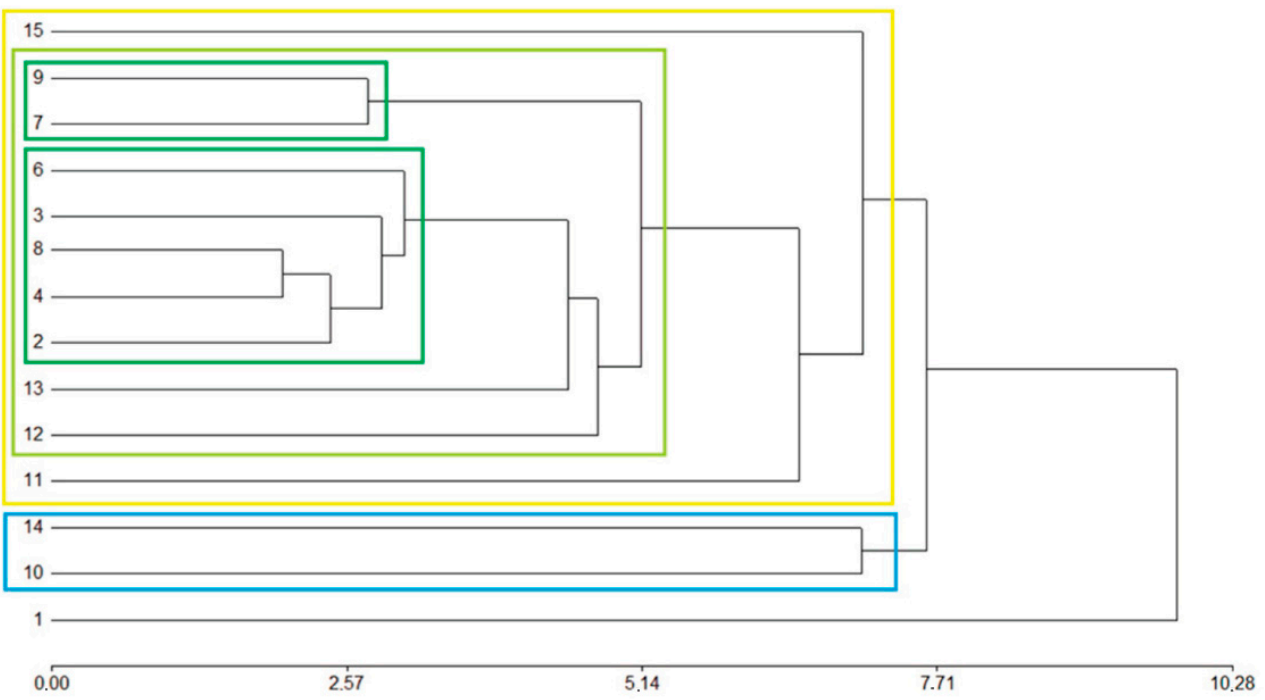

Figure 3. Dendrogram of agglomerative hierarchical clustering of sites according to: (A) Phytophthora spp. abundance (number of reads for each matched species) data matrix using Bray-Curtis similarity index and Ward clustering method; (B) Phytophthora spp. presence/absence data matrix using Euclidean distance index and average linkage clustering method.

When only the presence/absence of species was considered (Figure 3B), were the results of the clusters analysis very similar, but in this case sites 7 and 9 are grouped separately from the rest of sites with low species richness (green clade in Figure 3A). This may be due to the fact that these sites share in common the absence of $P$. austrocedri and P. ramorum. Moreover, these are the only two sites where P. austrocedri was not detected. The cophenetic correlation was 0.97 .

The frequency of most species was low (Table 2), almost $70 \%$ of the species being present in less than $25 \%$ of the sites, and $36 \%$ of the species in less than $10 \%$ of the sites, which means they were detected in only one site. The most frequent species were P. $\times$ cambivora $(90 \%)$, P. austrocedri $(86 \%)$, and P. ramorum $(79 \%)$.

Many of the recorded species represented new records in Argentina (P. ramorum, P. lateralis, P. kernoviae, P. obscura, P. ilicis Buddenh. and Roy A. Young, P. pseudosyringae T. Jung and Delatour, P. caryae N.J. Brazee, X. Yang and C.X. Hong/P. pini Leonian, P. bilorbang Aghighi, G.E. Hardy, J.K. Scott and T.I. Burgess, Safaief., Mostowf., G.E. Hardy and T.I. Burgess, P. idaei D.M. Kenn., P. mississippiae Xiao Yang, Copes and C.X. Hong, P. plurivora T. Jung and T.I. Burgess, and P. primulae J.A. Toml.). 
In addition, P. capensis Bezuid., Denman, A. McLeod and S.A. Kirk/P. citricola Sawada, P. cinnamomi Rands, P. megasperma Drechsler, and P. cryptogea Pethybr. and Laff./P. pseudocryptogea also represent new records in Patagonia. Other species previously reported in the study area, P. pseudotsugae [41] and Phytophthora taxon raspberry [42], were not detected in this study, suggesting that the Phytophthora diversity in Patagonia may be greater.

\subsection{Disease Distribution over Time}

Sampling site 11, even though it is inside Los Alerces National Park, differed from the other sites inside the park regarding Phytophthora species composition and abundance. This difference could be related to the fact that site 11 is subject to higher anthropogenic pressure than the other protected sites; besides the soils are more poorly drained in this area (Table 1).

The disease distribution over time showed that Austrocedrus disease began in the lower sector of the study area, in forests developing on the floodplain and terraces of the Grande river (yellow polygons in Figure 4). This low area, where fragmented forests grow on poorly to moderately well drained soils, is the sector with the highest anthropic pressure, where human settlements, cattle raising, and some forestry occur.

In the period 2005-2007 the disease showed a high progression [51] (orange polygons in Figure 4), implying a 50\% increment of the affected area, from 99 ha in 2005 to 148 ha in 2007, located almost entirely (98\%) under high-risk conditions, according to the model based on abiotic factors [35].

The affected area from 2007 to nowadays showed a lower rate of increase than in the previous studied period (red polygons in Figure 4). The studied area, which includes 900 ha of $A$. chilensis forests, currently shows 162.5 ha of diseased forests. Thus, while the disease progression rate was 24.5 ha year $^{-1}$ for the period 2005-2007 [51], it decreased to 1.2 ha year $^{-1}$ for the period 2007-2020.

The disease progressed in forests classified as at-risk according to the risk model based on environmental factors [35]. Ninety three percent of the forest area that became symptomatic during the 2007-2020 period was located in high risk site conditions, and 7\% in moderate risk sites (Figure S1B). According to the risk model, the disease progressed in forests located close to streams and on non-allophanic soils (in the study area this can be interpreted as poorly drained soils). Additionally, as shown in Figure 4B, many forests that became diseased surround the previously affected forests. Figure 5 shows the distribution of forests that became diseased in the period 2007-2020 in relation to the distance to trails. Many of these forests are located less than $100 \mathrm{~m}$ apart from these trails and paths.

The distribution of asymptomatic forests differed from that of diseased forests: they were located towards higher altitudes and slopes and farther from the Grande river (Figure 6), in areas less favorable for Phytophthora development and with low anthropogenic influence (Figure 4B; Figure S1). 
A

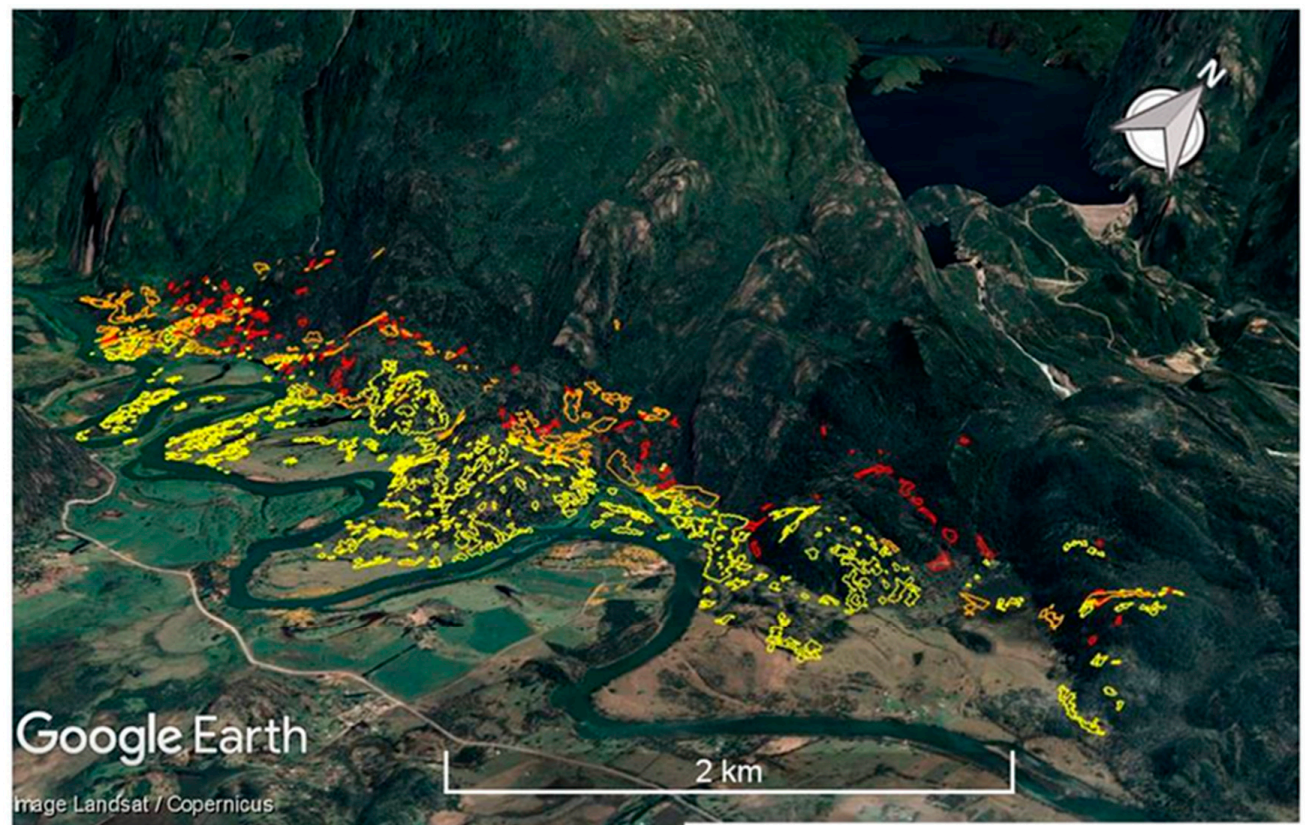

mage Landsat copernicus

mage $\sigma 2020$ CNES/Airbons ह

mage $\odot 2020$ Maxar technologies

$\square$ Austrocedrus disease distribution (mapped in 2005)

Data SIO, NOAA, US. Nayy, NGA, G巴BCO Ds ma

$\square$ Austrcedrus disease progression (2005-2007 period)

Austrcedrus disease progression (2007-2020 period)

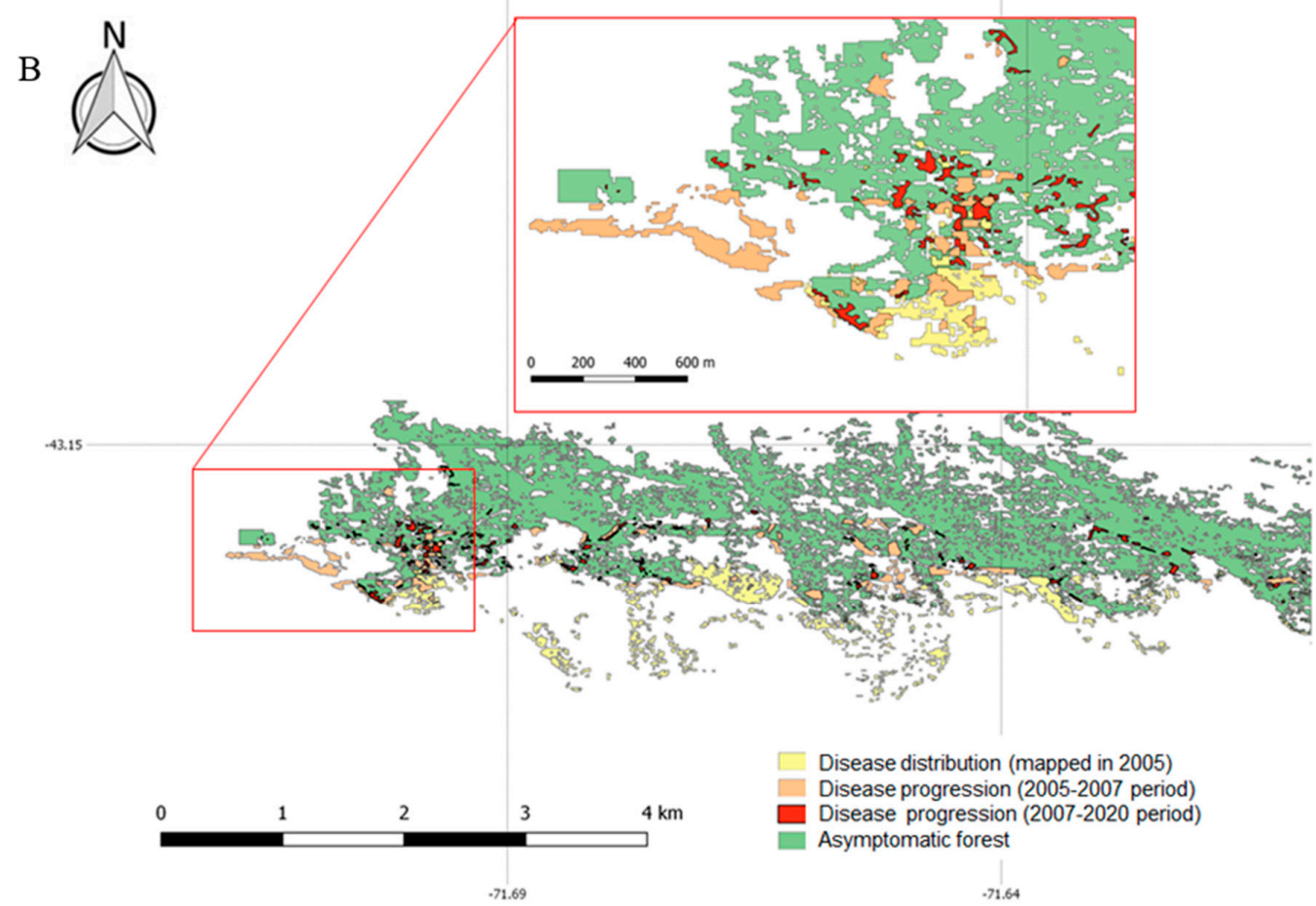

Figure 4. Austrocedrus disease distribution over time in an area from Los Alerces National Park. (A) Diseased forest distribution. (B) Distribution of diseased and asymptomatic forests. 


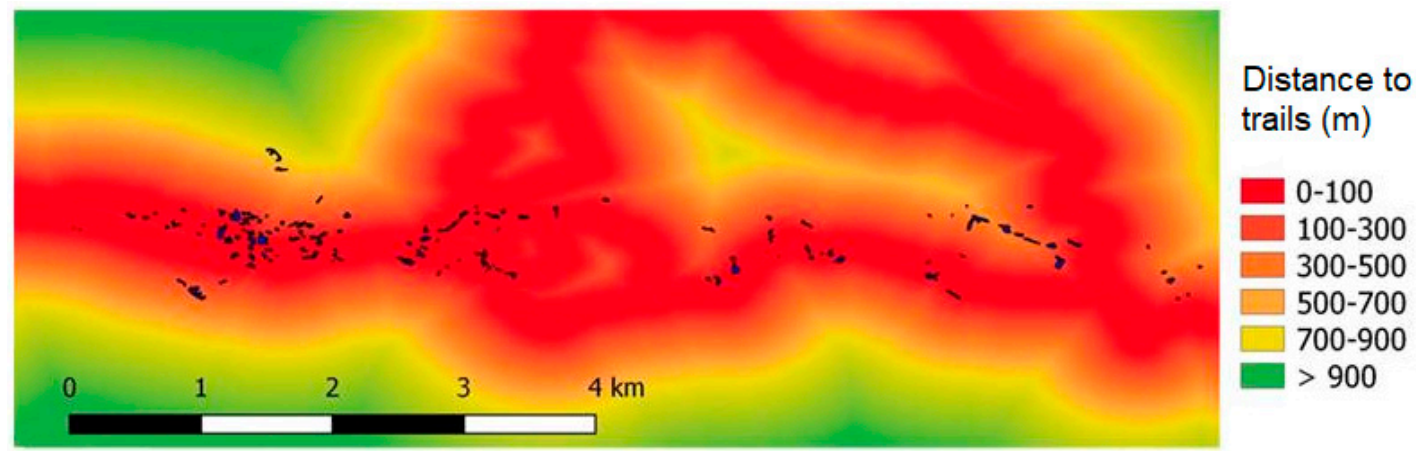

Figure 5. Distribution of A. chilensis forests that became diseased during 2007-2020 period (black spots) in relation to the distance to trails and paths. Color scale indicates the distance to trails across the study area.

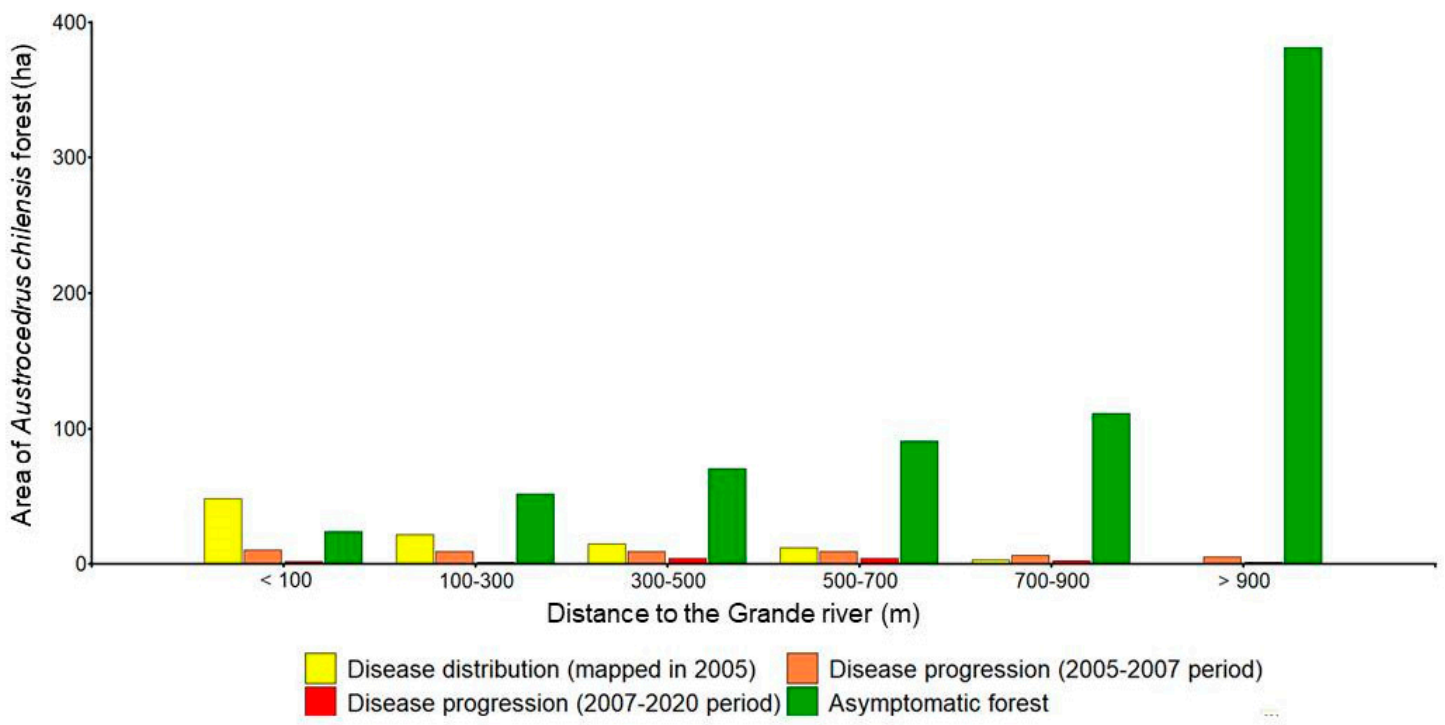

Figure 6. Area (ha) of diseased forest over time and area of currently asymptomatic forest according to the distance to the Grande river.

\section{Discussion}

\subsection{Phytophthora Diversity in Patagonian Soils}

Phytophthora austrocedri is the first Phytophthora species that was reported as a pathogen of forest trees in Patagonia. It has been detected along most of the distributional range of $A$. chilensis, mostly through isolation from necrotic lesions but also by baiting soil with $A$. chilensis seedlings $[3,24]$; however, its abundance had not been previously assessed. Even though metabarcoding can be considered as a semi-quantitative technique, the high number of reads indicates that $P$. austrocedri is much more abundant than other Phytophthora species in the sampled area. It showed the greatest relative abundance, with almost $43 \%$ of reads, and was detected in $86 \%$ of the sites, even where A. chilensis was absent (i.e., Nothofagus forests) and where it had not been previously reported. Riddell et al. [44] found similar results regarding $P$. austrocedri distribution in the UK and suggested that $P$. austrocedri might be well-adapted to survive in the soil in the absence of infected host material, or that it is capable of living in association with a wider range of plant species than is currently known. It was demonstrated that other Phytophthora species might be detected in roots and soils of asymptomatic non-hosts [53,54]. Thus, P. austrocedri could do the same.

High throughput metabarcode sequencing also allowed the detection of 12 Phytophthora species that were not previously reported in Argentina and four species that were not known to be present 
in Patagonia. Three of them are well-known woody plant pathogen species (P. ramorum, P. kernoviae, and $P$. lateralis), which represent a serious threat to plant health $[3,13,55-57]$. Phytophthora ramorum has a large range of hosts, and more than 100 plant species might be infected by this pathogen in forests, natural environments, or nurseries. Phytophthora ramorum was present in $78 \%$ of the sites, but abundant in three sites: two of mixed forest dominated by A. chilensis (sites 1 and 2), and one in a pure native N. pumilio forest (site 10). Interestingly, P. ramorum has been found causing bleeding stem lesions in Nothofagus obliqua (Mirb.) Oerst. in England [58]. No host has been identified yet to be affected by P. ramorum in Patagonia, but its presence highlights the possible risk of an outbreak. Many widely grown ornamental species are susceptible to P. ramorum, which could facilitate introduction into and invasions of new areas, acting as reservoirs of inocula. Phytophthora ramorum was detected only in one site in Los Alerces National Park, a highly visited area (site 8), which denotes the importance of protected areas in preventing the introduction of alien plants and pathogens. Phytophthora kernoviae, detected in more than $50 \%$ of the sites, exhibits comparable symptomatology and epidemiology to those of $P$. ramorum in the UK $[57,59,60]$. Those pathogens have overlapping geographic ranges in the UK and often concurrently invade similar niches. For this reason, it was speculated that P. kernoviae may also invade forests threatened by P. ramorum in the USA [61]. The same speculation might be made for the findings observed in Patagonia, since P. kernoviae was present in almost all the same sites as P. ramorum. Phytophthora kernoviae is known to cause disease in more than 15 plant genera, and rhododendron is the main host involved in pathogen transmission [62]. Sanfuentes et al. [63] reported for the first time the presence of P. kernoviae in native South American forests, obtained from necrotic lesions on fallen leaves of Drymis winteri J.R Forst. and G. Forst in the surface litter. The Valdivian rainforest of Chile and western Patagonia shares features of the ancient Gondwanaland flora with New Zealand. Recent findings support the New Zealand origin of P. kernoviae [64], which means that this species could be well adapted to coexist with some species of Valdivian rainforests. The wide distribution of these two pathogenic species in Patagonia, detected all along the range N-S of the sampling area, could indicate that they are well established in Patagonia. However, isolation is needed to confirm this hypothesis. Phytophthora lateralis was detected in two A. chilensis stands, one being a diseased stand in a heavily anthropized area and the other a burned stand in the national park. This pathogen, with few exceptions, is limited to hosts in the Cupressaceae [56,65-67]. Although P. lateralis has not been previously isolated in declining $A$. chilensis forests, it is unknown whether this pathogen could contribute to the general decline of the tree.

The most frequent and widely distributed species was found to be P. $\times$ cambivora (Table 2). This species is the causal agent of seedling blight, root rot, collar and root rot, trunk canker, ink disease, and wilting for more than 30 plant species, including many woody plants and crops [65,68]. Phytophthora $\times$ cambivora has been isolated from soil in different forests and stands, and detected in public gardens and amenity woodlands in Europe and the USA [44,69-71]. This species was previously isolated from soils of $A$. chilensis diseased forests [42]. At present, $P$. $\times$ cambivora seems not to be causing disease in Patagonian forests, but since it has also been detected near, or in areas with agricultural use, it may represent a threat to some economically important woody plants.

Phytophthora syringae showed low frequency (present in only two sites) in the metabarcoding study. However, it was considered a ubiquitous species, frequently isolated from native forest soil samples of Patagonia [42]. A possible explanation is that the isolates previously identified as P. syringae might have been misidentified and could correspond to P. obscura, a closely-related species, with very similar morphological and ecological characteristics [23], which was much more frequently detected (Table 2). In contrast, $P$. obscura has been rarely detected in the USA and Europe $[23,44]$. Phytophthora syringae and P. obscura are primarily distinguished by molecular methods. Additionally, many isolates of P. pseudosyringae have erroneously been identified as P. syringae by different authors due to their similarity in morphological and physiological features [72]. Besides, it is unknown whether some DNA sequences are amplified more efficiently than others during PCR, leading to the presence of artifacts in the metabarcoding analysis. Riddell et al. [44] reported P. syringae as a frequently occurring species in 
soils in public gardens and amenity woodlands in Britain, using the same methodology, suggesting it should amplify efficiently here. However, in their control mixture P. boehmeriae failed to amplify, which was explained by PCR primer mismatches leading to other species being preferentially amplified.

Phytophthora pseudosyringae was initially isolated from rhizosphere soil of declining oak forests and was also found causing necrosis of fine roots and stems of different tree species [72]. Interestingly, it was also recently found causing stem bleeding cankers in Nothofagus obliqua (Mirb.) Oerst. in Chile and the UK [73,74]. In pathogenicity trials, N. alpina (Poepp. and Endl.) Oerst. and N. dombeyi (Mirb.) Oerst. were also susceptible to this pathogen [73]. Since P. pseudosyringae was detected in Nothofagus forests, the potential of P. pseudosyringae to cause damage in natural Nothofagus stands in Patagonia should be explored.

In the present study, P. chlamydospora was detected in soils from A. chilensis, Nothofagus, mixed forests, and a highly disturbed place near farms (sites 1, 10,13, and 14). It was previously reported to be present in streams of A. chilensis forests [42]. Phytophthora chlamydospora is a cosmopolitan species commonly found in streams and wet soil worldwide and is a pathogen of some riparian tree species $[75,76]$. However, despite its abundance in streams, there is generally no evidence of disease in the surrounding vegetation in the study area. In contrast, $P$. chlamydospora appears to be a pathogen of woody plants and horticulturally valuable species [77], which could have implications for site 1 . The other species found in clade $6 \mathrm{~b}$ of the phylogeny of Yang et al. [22] (P. gonapodyides, P. mississipiae, P. bilorbang, P. megasperma) were associated with heavy wet soils or samples taken next to streams. Like P. chlamydospora, these species have been detected worldwide in soil, watercourses, or irrigation systems and are considered to be in general minor to moderate pathogens of some plants $[65,75,78-83]$. Phytophthora gonapodyides has been previously recovered from streams of $A$. chilensis stands [42], but no association of this species with Austrocedrus disease was evidenced.

Phytophthora cactorum occurs worldwide and causes root and collar rots, fruit rots, cankers, leaf blights, wilts, and seedling blights in more than 200 plant species, including horticultural species and woody plants [65]. Clade 1 Phytophthora species related to P. cactorum, such as P. aleatoria and P. pseudotsugae, may have a specific association with hosts in the family Pinaceae $[84,85]$. In particular, P. cactorum is associated with more than 30 Pinaceae host species, such as Pinus ponderosa, and some Cupressaceae [84]. Pinus ponderosa P. Lawson and C. Lawson is the exotic tree species most widely planted along Patagonia. Phytophthora aleatoria/P. cactorum was detected on a private ranch (site 15, Corcovado ST) in an A. chilensis stand next to a P. ponderosa plantation, which makes it necessary to monitor its health status. Phytophthora cactorum was previously isolated from declining A. chilensis forests [41], but the possible role of this species in the decline of the tree was not explored. Phytophthora idaei, another species in clade 1 known to be pathogenic to raspberries, was detected in site 1 near farms that produce raspberries, among other plant species. Noteworthily, in this area, raspberry plants with symptoms of Phytophthora infection are under study (Vélez and Marfetán pers. comm.). Similarly, species in the "P. citricola complex" were reported to have a wide range of hosts with economic and/or ecological importance [65,86-88]. In particular, P. plurivora was found in site 15 (a ranch with different land uses), P. capensis/P. citricola in site 1 , and P. caryae/P. pini in a grazed area with $A$. chilensis diseased stands (site 14).

Phytophthora ilicis and P. cinnamomi were detected at low frequency in the present study. While P. ilicis has the shrub Ilex aquifolim as the only known host, P. cinnamomi is a serious pathogen of more than 1000 plant species, including ornamentals, woody plants, and trees $[65,89]$. Other species rarely detected in this study were P. primulae (site 1) in subclade $8 \mathrm{~b}$, and P. pseudocryptogea (site 1 ) in subclade 8a [22]. Species in subclade $8 \mathrm{~b}$ are host specific, slow-growing, and specifically infect herbaceous crops at low temperatures $[65,90]$, while P. pseudocryptogea and its close relatives have been isolated from soil, irrigation water, and numerous hosts $[65,69,91]$. The biological significance of the presence of these species in Patagonia deserves further studies.

Many of the Phytophthora species detected in this study have been found in nurseries in Europe and the USA $[55,92,93]$. Nursery plants are shipped inside the country and intra- and inter-continentally. 
Since fungicides are used as a common practice, pathogens might be present but not detected in plants that have a high chance of contributing to Phytophthora spread [55]. Thus, plant trade could have been involved in the introduction of Phytophthora species into Patagonia through contaminated plants and soils. In this sense, it would be necessary to conduct a survey of Phytophthora in nurseries in Patagonia. Whether DNA detection indicates the presence of live inocula in our study needs to be confirmed by other approaches, such as baiting or RNA-based methodology. If that were the case, it would evidence the ability of these Phytophthora species to survive in soil and therefore to be potentially transferred to susceptible plants.

Since in this study samples were mostly taken close to roads, the diversity observed may reflect, at least partially, the invasions produced by human activities. Studies of this type in areas with different types of land use but far from roads, and pristine ones, will contribute to differentiating ubiquitous species from those with restricted distribution, which could reveal recent invasions.

\subsection{Anthropogenic Factors in Relation to Phytophthoralinvasions and Plausible Management Strategies}

The similarities in Phytophthora species composition and abundance between study sites were mainly associated with land use and anthropogenic impact. The sites with higher Phytophthora richness were those with higher levels of human activity and the sites with lower richness were those with restricted human activities. These results highlight the influences of anthropogenic factors on the spread of invasive Phytophthoras, as was previously reported for Austrocedrus disease [36,51,94]. Several studies show that human activities act as drivers of Phytophthora invasions, e.g., [56,95-97].

The different methodological approaches addressed in this work highlight the importance of anthropogenic and abiotic features as conditioning factors on both the diversity of Phytophthora and on the spatial distribution of the disease. In the sector of Los Alerces National Park where the distribution of the disease was studied over time, it was found that the disease began in the floodplain and terraces of the Grande river. The distribution of the first affected forests and the spread in the period 2005-2007 coincide with the poorest drained soils, but also with the highest anthropogenic pressure, where human settlements, cattle raising, and some forestry occur. At the end of the twentieth century, the disease was practically limited to the river coastline. In fact, many stands considered asymptomatic in 2000, located on the river plain [31], showed disease symptoms or even high mortality in 2007 [51].

Austrocedrus disease progression, both in the period 2005-2007 and in 2007-2020 occurred over forests environmentally classified as at risk, i.e., near to water courses and on poorly drained soils [35]. However, the increment in the affected area was quite different between both periods, being lower for the last one. The disease spread from 2007 to nowadays is affecting forest areas further from the Grande river, in sites prone to the disease but at higher altitudes, shifting away from the area with the greatest anthropogenic influence. Anyway, disease progress is still conditioned by anthropogenic factors, as shown by its relationship with the nearness to trails and paths. The decrease found in the rate of disease progression in the last period could also be influenced by climate conditions. Since 2003, the precipitation in the study area has been below the average value $[98,99]$, which can affect soil moisture and thus Phytophthora dispersion [65].

The importance of anthropogenic factors to Austrocedrus disease spread was also evidenced by its distribution in lands with productive uses vs. protected areas. Austrocedrus disease distribution was previously evaluated in the Rio Grande Valley, in Chubut province, where a sector with high anthropogenic pressure and a protected area (Los Alerces National Park) coexist, partially overlapping the current study area of the disease distribution over time [100]. Outside the protected area, where the forests are closer to houses and agricultural fields and crossed by roads, not only is the proportion of the affected area higher (30\% vs. $1 \%$, outside and inside the protected area, respectively), but the disease is also widespread almost throughout the area. Only the highest, steepest, and most inaccessible forests are free from the disease, highlighting the influences of anthropogenic factors on disease dispersion (Figure S2). While inside the National Park, as it was found in our study, the affected area is circumscribed to the lowest sector, closer to the Grande river. The influences of anthropogenic factors 
on Austrocedrus disease distribution are more pieces of evidence that $P$. austrocedri is an exotic invasive species. The importance of anthropogenic factors to P. austrocedri spread was shown for J. communis woodlands in UK, where P. austrocedri DNA was consistently found in soil from footpaths and animal tracks at infected woodlands and from boots after walking through infected sites [101]. It seems that the natural spread of $P$. austrocedri is most likely limited to a "within-site" distribution via soil water run-off, aided by animal and human activity that further move infested soil and plant debris [40].

Since $A$. chilensis forests grow in valleys and low slopes, their distribution overlaps with the areas with most anthropogenic impacts (farming, livestock, urban planning, and touristic and recreational activities), and P. austrocedri was found to be widely distributed in Patagonia. Not only the eradication, but also the control of the disease spread seem very difficult, at least in areas with anthropogenic activity. However, certain control and management strategies might mitigate this negative impact on $A$. chilensis forests. Mainly in protected areas, where anthropogenic impact could be minimized, it would be possible to avoid further spread, especially towards sites environmentally unfavorable for the pathogen [36] and to areas where there are other susceptible species.

Regarding control measures, integrated strategies should be considered, including chemical and biological control, and field identification of resistant trees as material sources for restoration and reforestation. Phosphite-based fungicides have very low phytotoxicity to $A$. chilensis, even at high concentrations [29], showing great potential to be used in natural ecosystems to control Austrocedrus disease. Even though chemical control is not feasible at the landscape scale, it may be an option to control the disease in specific, limited places such as forests of high conservation value, and to protect healthy sites by making a barrier of treated trees at the possible disease-entry points (such as roadsides and streams). The first assay of treatment with fosetyl-Al and potassium phosphite in a stand of a natural forest located in a protected area is in progress (Greslebin and Romano pers. comm.). Biocontrol strategies were also found to be useful alternatives to chemical fungicides in controlling P. austrocedri [30]. A program to evaluate trees for resistance is underway. Although a low frequency of resistance to $P$. austrocedri was found in natural populations (Vélez pers. comm.), selected trees are being vegetatively propagated for further studies for resistance [102].

Since many Phytophthora species were detected in this study, it is necessary to adopt and promote good practices in Patagonia to avoid the possible transfer of soil-borne Phytophthoras within. Management measures should involve implementing appropriate biosecurity, including adequately cleaning tools, vehicles, and shoes before moving to other sites, using safe water in irrigation systems, avoiding changes in watercourses, regulating activities such as forestry, cattle raising, and tourism, and selecting disease free plants from nurseries with verifiable Phytophthora control and management plans, among others.

\section{Conclusions}

Phytophthora austrocedri is widely distributed in Patagonia. Moreover, many previously unrecorded Phytophthoras, including highly invasive pathogenic species, were detected in soil, signaling a high risk of establishment of potentially pathogenic species in Patagonian ecosystems. Phytophthora diversity was highly influenced by anthropogenic impact. Species richness was higher in areas with high human activities than in protected areas or in areas with low anthropogenic impact. The distribution of Austrocedrus disease and the affected area over time were also enhanced by anthropogenic impact.

This study evidenced that it is necessary to urgently adopt management measures in order to control the spread of P. austrocedri and other invasive Phytophthora species in Patagonia.

Supplementary Materials: The following are available online at http://www.mdpi.com/1999-4907/11/11/1223/s1. Figure S1. (A) Study area of Austrocedrus disease distribution over time. (B) Austrocedrus disease risk according to abiotic factors (risk model based on La Manna et al. 2012 [1]. (C) Austrocedrus disease distribution over time. Figure S2. Distribution of Austrocedrus chilensis forests in Chubut province, Argentina (source: Forest Inventory, report by CIEFAP, 2016) and the detail of the distribution of diseased and asymptomatic forests in Río Grande valley (source: La Manna et al. 2008 [2]. 
Author Contributions: Conceptualization, formal analysis, and manuscript writing were done by A.G., L.L.M., and M.L.V.; all authors contributed to methodology, investigation, and validation; M.E., M.L.V., and A.G. collected the soil samples for metabarcoding analysis; P.E.H. performed sequencing; P.C. conducted bioinformatic analysis; L.L.M., M.T., and F.G. did progression analysis. All authors have read and agreed to the published version of the manuscript.

Funding: This research was founded by Agencia Nacional de Promoción Científica y Técnica (ANPCyT-FONCyT) PICT-2012-0733 and PICT-2015-1933.

Acknowledgments: We would like to thank Sarah Green for having the original idea of collecting the soil samples in Patagonia and Béatrice Henricot for preparing the DNA libraries. The British Society for Plant Pathology is deeply thanked for providing a Travel Bursary to M.E. that allowed doing the soil sampling.

Conflicts of Interest: The authors declare no conflict of interest.

\section{References}

1. Bran, D.; Pérez, A.; Barrios, D.; Pastorino, M.; Ayesa, J. Eco-Región Valdiviana: Distribución Actual de los Bosques de "Ciprés de la Cordillera" (Austrocedrus chilensis)—Escala 1:250.000; Informe Preliminar; INTA, APN, FVSA: Bariloche, Argentina, 2002; p. 12.

2. Ellison, A.M.; Bank, M.S.; Clinton, B.D.; Colburn, E.A.; Elliott, K.; Ford, C.R.; Foster, D.R.; Kloeppel, B.D.; Knoepp, J.D.; Lovett, G.M.; et al. Loss of foundation species: Consequences for the structure and dynamics of forested ecosystems. Front. Ecol. Environ. 2005, 3, 479-486. [CrossRef]

3. Greslebin, A.G.; Hansen, E.M. Pathogenicity of Phytophthora austrocedrae on Austrocedrus chilensis and its relation with "Mal del Ciprés" in Patagonia. Plant Pathol. 2010, 59, 604-612. [CrossRef]

4. Havrylenko, M.; Rosso, P.; Fontenla, S. Austrocedrus chilensis. Contribución al estudio de la mortalidad en Argentina. Bosque 1989, 10, 29-36. [CrossRef]

5. Filip, G.M.; Rosso, P.H. Cypress mortality (mal del ciprés) in the Patagonian Andes: Comparisons with similar forest diseases and declines in North America. Eur. J. For. Pathol. 1999, 29, 89-96. [CrossRef]

6. Barroetaveña, C.; Rajchenberg, M. Hongos Aphyllophorales (Basidiomycetes) que causan pudriciones en Austrocedrus chilensis en pie. Bol. Soc. Arg. Bot. 1996, 31, 201-216.

7. Greslebin, A.G.; Hansen, E.M.; Sutton, W. Phytophthora austrocedrae sp. nov., a new species associated with Austrocedrus chilensis mortality in Patagonia (Argentina). Mycol. Res. 2007, 111, 308-316. [CrossRef]

8. Baldini, A.; Oltremari, J.; Holmgren, A. Efecto de Cinara cupressi (Hemiptera: Aphididae) sobre el ciprés de la cordillera (Austrocedrus chilensis) después de aplicar control químico. Ciencia e Investig. Agrar. 2008, 35, 341-350. [CrossRef]

9. Montalva, C.; Rojas, E.; Ruiz, C.; Lanfranco, D. El pulgón del ciprés en Chile: Una revisión de la situación actual y antecedentes del control biológico. Bosque 2010, 31, 81-88. [CrossRef]

10. De Errasti, A. Cinara cupressi en el Parque Nacional Los Alerces; Technical Report; Centro de Investigación y Extensión Forestal Andino Patagónico: Chubut, Argentina, 2015. [CrossRef]

11. Mundo, I.A.; El Mujtar, V.A.; Perdomo, M.H.; Gallo, L.A.; Villalba, R.; Barrera, M.D. Austrocedrus chilensis growth decline in relation to drought events in northern Patagonia, Argentina. Trees 2010, 24, 561-570. [CrossRef]

12. Amoroso, M.; Larson, B. Stand development patterns as a consequence of the mortality in Austrocedrus chilensis forests. For. Ecol. Manage. 2010, 259, 1981-1992. [CrossRef]

13. Green, S.; Elliot, M.; Armstrong, A.; Hendry, S.J. Phytophthora austrocedrae emerges as a serious threat to juniper (Juniperus communis) in Britain. Plant Pathol. 2015, 64, 456-466. [CrossRef]

14. Amoroso, M.M.; Daniels, L.D.; Villalba, R.; Cherubini, P. Does drought incite tree decline and death in Austrocedrus chilensis forests? J. Veg. Sci. 2015, 26, 1171-1183. [CrossRef]

15. Jung, T.; Blaschke, H.; Oßwald, W. Involvement of soilborne Phytophthora species in Central European oak decline and the effect of site factors on the disease. Plant Pathol. 2000, 49, 706-718. [CrossRef]

16. Anacker, B.L.; Rank, N.E.; Hüberli, D.; Garbelotto, M.; Gordon, S.; Harnik, T.; Whitkus, R.; Meentemeyer, R. Susceptibility to Phytophthora ramorum in a key infectious host: Landscape variation in host genotype, host phenotype, and environmental factors. New Phytol. 2008, 177, 756-766. [CrossRef] [PubMed]

17. Donald, F.; Green, S.; Searle, K.; Cunniffe, N.J.; Purse, B.V. Small scale variability in soil moisture drives infection of vulnerable juniper populations by invasive forest pathogen. For. Ecol. Manag. 2020, 473, 118324. [CrossRef] 
18. Green, S.; MacAskill, G.A.; Dun, H.; Armstrong, A.C.; Henricot, B. First report of Phytophthora austrocedri infecting Nootka cypress in Britain. New Dis. Rep. 2016, 33, 2044-0588. [CrossRef]

19. Henricot, B.; Pérez-Sierra, A.; Armstrong, A.C.; Sharp, P.M.; Green, S. Morphological and genetic analyses of the invasive forest pathogen Phytophthora austrocedri reveal that two clonal lineages colonized Britain and Argentina from a common ancestral population. Phytopathology 2017, 107, 1532-1540. [CrossRef]

20. Taccari, L.E.; Greslebin, A.G.; Salgado Salomón, M.E.; Vélez, M.L. Two conifer species native to Patagonia threatened by Phytophthora austrocedri. For. Pathol. 2019, 49, e12496. [CrossRef]

21. Martin, F.N.; Blair, J.E.; Coffey, M.D. A combined mitochondrial and nuclear multilocus phylogeny of the genus Phytophthora. Fungal Genet. Biol. 2014, 66, 19-32. [CrossRef]

22. Yang, X.; Tyler, B.M.; Hong, C. An expanded phylogeny for the genus Phytophthora. IMA Fungus 2017, 8, 355-384. [CrossRef]

23. Grünwald, N.J.; Werres, S.; Goss, E.M.; Taylor, C.R.; Fieland, V.J. Phytophthora obscura sp. nov., a new species of the novel Phytophthora subclade 8d. Plant Pathol. 2012, 61, 610-622. [CrossRef]

24. Vélez, M.L.; Coetzee, M.P.A.; Wingfield, M.J.; Rajchenberg, M.; Greslebin, A.G. Evidence of low levels of genetic diversity for the Phytophthora austrocedrae population in Patagonia, Argentina. Plant Pathol. 2014, 63, 212-220. [CrossRef]

25. Vélez, M.L.; Silva, P.V.; Troncoso, O.A.; Greslebin, A.G. Alteration of physiological parameters of Austrocedrus chilensis by the pathogen Phytophthora austrocedrae. Plant Pathol. 2012, 61, 877-888. [CrossRef]

26. Troncoso, O.A. Histología de la Afección de Phytophthora austrocedri en los Tejidos de Conducción de Austrocedrus chilensis. Ph.D. Thesis, Universidad Nacional de la Patagonia San Juan Bosco, Comodoro Rivadavia, Argentina, 11 May 2018.

27. Olate, V.R.; Vélez, M.L.; Greslebin, A.; Schmeda-Hirschmann, G. Phytophthora austrocedri Elicitates Changes in Diterpene Profile of Austrocedrus chilensis. Molecules 2015, 20, 15084-15097. [CrossRef] [PubMed]

28. Troncoso, O.; Greslebin, A. Trabeculae in Patagonian mountain cypress (Austrocedrus chilensis) associated with Phytophthora austrocedri infection. IAWA J. 2018, 39, 209-220. [CrossRef]

29. Silva, P.; Vélez, M.; Hernández Otaño, D.; Greslebin, A. Action of fosetil-al and metalaxil against Phytophthora austrocedri. For. Pathol. 2016, 46, 54-66. [CrossRef]

30. Marfetán, J.A.; Greslebin, A.G.; Taccari, L.E.; Vélez, M.L. Rhizospheric microorganisms as potential biocontrol agents against Phytophthora austrocedri. Eur. J. Plant Pathol. 2020, 158, 721-732. [CrossRef]

31. La Manna, L.; Rajchenberg, M. Soil properties and Austrocedrus chilensis decline in Central Patagonia, Argentina. Plant Soil. 2004, 263, 29-41. [CrossRef]

32. La Manna, L.; Matteucci, S.D. Spatial and temporal patterns at small scale in Austrocedrus chilensis diseased forests and their effect on disease progression. Eur. J. For. Res. 2012, 131, 1487-1499. [CrossRef]

33. Baccalá, N.; Rosso, P.; Havrylenko, M. Austrocedrus chilensis mortality in the Nahuel Huapi National Park (Argentina). For. Ecol. Manage. 1998, 109, 261-269. [CrossRef]

34. La Manna, L.; Matteucci, S.D.; Kitzberger, T. Abiotic factors related to the incidence of the Austrocedrus chilensis disease syndrome at a landscape scale. For. Ecol. Manag. 2008, 256, 1087-1095. [CrossRef]

35. La Manna, L.; Matteucci, S.D.; Kitzberger, T. Modelling potential Phytophthora disease risk in Austrocedrus chilensis forests of Patagonia. Eur. J. For. Res. 2012, 131, 323-337. [CrossRef]

36. La Manna, L.; Greslebin, A.; Matteucci, S.D. Applying Cost-distance analysis for forest disease risk mapping: Phytophthora austrocedrae as an example. Eur. J. For. Res. 2013, 132, 877-885. [CrossRef]

37. Rhoades, C.; Brosi, S.; Dattilo, A.; Vincelli, P. Effect of soil compaction and moisture on incidence of Phytophthora root rot on American chestnut (Castanea dentata) seedlings. For. Ecol. Manag. 2003, 184, 47-54. [CrossRef]

38. Jung, T.; Blaschke, M. Phytophthora root and collar rot of alders in Bavaria: Distribution, modes of spread and possible management strategies. Plant Pathol. 2004, 53, 197-208. [CrossRef]

39. Jönsson, U.; Jung, T.; Sonesson, K.; Rosengren, U. Relationships between health of Quercus robur, occurrence of Phytophthora species and site conditions in southern Sweden. Plant Pathol. 2005, 54, 502-511. [CrossRef]

40. Riddell, C.E.; Dun, H.F.; Elliot, M.; Armstrong, A.C.; Clark, M.; Forster, J.; Hedley, P.E.; Green, S. Detection and spread of Phytophthora austrocedri within infected Juniperus communis woodland and diversity of co-associated Phytophthoras as revealed by metabarcoding. For. Pathol. 2020, e12602. [CrossRef] 
41. Rajchenberg, M.; Barroetaveña, C.; Cwielong, P.P.; Rossini, M.; Cabral, D.; Sívori, A. Preliminar survey of Fungi associated with the decline of Ciprés in Patagonia. In Proceedings of the 9th International Conference on Root and Butt-Rots, Carcans, France, 1-7 September 1997; INRA: Paris, France, 1998; pp. 235-244.

42. Greslebin, A.; Hansen, E.; Winton, L.; Rajchenberg, M. Phytophthora species from declining Austrocedrus chilensis forests in Patagonia, Argentina. Mycologia 2005, 97, 218-228. [CrossRef]

43. Burgess, T.I.; White, D.; McDougall, K.M.; Garnas, J.; Dunstan, W.A.; Catalá, S.; Angus Carnegie, J.; Worboys, S.; Cahill, D.; Vettraino, A.M.; et al. Distribution and diversity of Phytophthora across Australia. Pacific Conserv. Biol. 2017, 23, 150-162. [CrossRef]

44. Riddell, C.E.; Frederickson-Matika, D.; Armstrong, A.C.; Elliot, M.; Forster, J.; Hedley, P.E.; Morris, J.; Thorpe, P.; Cooke, D.E.; Pritchard, L.; et al. Metabarcoding reveals a high diversity of woody host-associated Phytophthora spp. in soils at public gardens and amenity woodlands in Britain. PeerJ 2019, 7, e6931. [CrossRef]

45. Scibetta, S.; Schena, L.; Chimento, A.; Cacciola, S.O.; Cooke, D.E. A molecular method to assess Phytophthora diversity in environmental samples. J. Microbiol Methods. 2012, 88, 356-368. [CrossRef] [PubMed]

46. Illumina. 16S Metagenomic Sequencing Library Preparation; Illumina: San Diego, CA, USA, 2013; p. 28.

47. Bolger, A.M.; Lohse, M.; Usadel, B. Trimmomatic: A flexible trimmer for Illumina sequence data. Bioinformatics 2014, 30, 2114-2120. [CrossRef] [PubMed]

48. Magoč, T.; Salzberg, S.L. FLASH: Fast length adjustment of short reads to improve genome assemblies. Bioinformatics 2011, 27, 2957-2963. [CrossRef] [PubMed]

49. Martin, M. Cutadapt removes adapter sequences from high-throughput sequencing reads. EMBnet. J. 2011, 17, 10-12. [CrossRef]

50. Di Rienzo, J.A.; Casanoves, F.; Balzarini, M.G.; González, L.; Tablada, M.; Robledo, Y.C. InfoStat; versión 2011; Grupo InfoStat, FCA, Universidad Nacional de Córdoba: Córdoba, Argentina, 2011.

51. La Manna, L.; Greslebin, A.; Matteucci, S.D. Avance de la mortalidad de los bosques de Austrocedrus chilensis a escala de paisaje. Rev. Asoc. Arg. Ecol. Paisaje 2014, 5, 17-24.

52. QGIS Development Team. QGIS Geographic Information System. Open Source Geospatial Foundation Project. 2018. Available online: http://qgis.osgeo.org (accessed on 24 June 2020).

53. Crone, M.; McComb, J.A.; O’Brien, P.A.; Hardy, G.E.S.J. Annual and herbaceous perennial native Australian plant species are symptomless hosts of Phytophthora cinnamomi in the Eucalyptus marginata (jarrah) forest of Western Australia. Plant Pathol. 2013, 62, 1057-1062. [CrossRef]

54. Prigigallo, M.I.; Mosca, S.; Cacciola, S.O.; Cooke, D.E.L.; Schena, L. Molecular analysis of Phytophthora diversity in nursery-grown ornamental and fruit plants. Plant Pathol. 2015, 64, 1308-1319. [CrossRef]

55. Grünwald, N.J.; Garbelotto, M.; Goss, E.M.; Heungens, K.; Prospero, S. Emergence of the sudden oak death pathogen Phytophthora ramorum. Trends Microbiol. 2012, 20, 131-138. [CrossRef]

56. Hansen, E.M.; Goheen, D.J.; Jules, E.S.; Ullian, B. Managing PortOrford-Cedar and the introduced pathogen Phytophthora lateralis. Plant Dis. 2000, 84, 4-14. [CrossRef]

57. Brasier, C.M.; Beales, P.A.; Kirk, S.A.; Denman, S.; Rose, J. Phytophthora kernoviae sp. nov., an invasive pathogen causing bleeding stem lesions on forest trees and foliar necrosis of ornamentals in the UK. Mycol. Res. 2005, 109, 853-859. [CrossRef]

58. Webber, J.F. Status of Phytophthora ramorum and P. kernoviae in Europe. In Proceedings of the Sudden Oak Death Third Science Symposium; General Technical Report (GTR) PSW-GTR-214; Frankel, S.J., Kliejunas, J.T., Palmieri, K.M., Eds.; US Department of Agriculture, Forest Service, Pacific Southwest Research Station: Albany, CA, USA, 2008; pp. 19-26.

59. Beales, P.A.; Lane, C.R.; Barton, V.C.; Giltrap, P.M. Phytophthora kernoviae on ornamentals in the UK. EPPO Bull. 2006, 36, 377-379. [CrossRef]

60. Defra. Consultation on Future Management of Risks from Phytophthora ramorum and Phytophthora kernoviae; Department for Environment, Food and Rural Affairs: London, UK, 2008.

61. Fichtner, E.J.; Rizzo, D.M.; Kirk, S.A.; Webber, J.F. Infectivity and sporulation potential of Phytophthora kernoviae to select North American native plants. Plant Pathol. 2012, 61, 224-233. [CrossRef]

62. Fera. Fera List of Natural Hosts of Phytophthora kernoviae with Symptoms; The Food and Environment Research Agency: London, UK, 2010.

63. Sanfuentes, E.; Fajardo, S.; Sabag, M.; Hansen, E.; González, M. Phytophthora kernoviae isolated from fallen leaves of Drymis winteri in native forest of southern Chile. Australasian Plant Dis Notes. 2016, 11, 19. [CrossRef] 
64. Studholme, D.J.; Panda, P.; Sanfuentes Von Stowasser, E.; González, M.; Hill, R.; Sambles, C.; Grant, M.; Williams, N.M.; McDougal, R.L. Genome sequencing of oomycete isolates from Chile supports the New Zealand origin of Phytophthora kernoviae and makes available the first Nothophytophthora sp. genome. Mol. Plant Pathol. 2019, 20, 423-431. [CrossRef] [PubMed]

65. Erwin, D.; Ribeiro, O. Phytophthora Diseases Worldwide; APS Press: St. Paul, MN, USA, 1996; p. 562.

66. Schlenzig, A.; Campbell, R.; Mulholland, V. Thuja occidentalis: A new host for Phytophthora lateralis. New Dis Rep. 2011, 24. [CrossRef]

67. Schlenzig, A.; Campbell, R.; Eden, R. First report of Phytophthora lateralis on Chamaecyparis pisifera. New Dis. Rep. 2014, 29, 2014. [CrossRef]

68. Orlikowski, L.B.; Oszako, T. Phytophthora cambivora on Alnus glutinosa: Isolation and colonisation of plants. J. Plant Prot. Res. 2005, 45, 267-272.

69. Vettraino, A.M.; Barzanti, G.P.; Bianco, M.C.; Ragazzi, A.; Capretti, P.; Paoletti, E.; Luisi, N.; Anselmi, N.; Vannini, A. Occurrence of Phytophthora species in oak stands in Italy and their association with declining oak trees. For. Pathol. 2002, 32, 19-28. [CrossRef]

70. Jung, T. Beech decline in Central Europe driven by the interaction between Phytophthora infections and climatic extremes. For. Pathol. 2009, 39, 73-94. [CrossRef]

71. Hansen, E.M.; Reeser, P.W.; Sutton, W. Phytophthora beyond agriculture. Annu. Rev. Phytopathol. 2012, 50, 359-378. [CrossRef]

72. Jung, T.; Nechwatal, J.; Cooke, D.E.; Hartmann, G.; Blaschke, M.; Oßwald, W.F.; Duncan, J.M.; Delatour, C. Phytophthora pseudosyringae sp. nov., a new species causing root and collar rot of deciduous tree species in Europe. Mycol. Res. 2003, 107, 772-789. [CrossRef] [PubMed]

73. Fajardo, S.N.; Valenzuela, S.; Dos Santos, A.F.; González, M.P.; Sanfuentes, E.A. Phytophthora pseudosyringae associated with the mortality of Nothofagus obliqua in a pure stand in central-southern Chile. For. Pathol. 2017, 47, e12361. [CrossRef]

74. Scanu, B.; Webber, J.F. Dieback and mortality of Nothofagus in Britain: Ecology, pathogenicity and sporulation potential of the causal agent Phytophthora pseudosyringae. Plant Pathol. 2016, 65, 26-36. [CrossRef]

75. Brasier, C.M.; Cooke, D.E.L.; Duncan, J.M.; Hansen, E.M. Multiple new phenotypic taxa from trees and riparian ecosystems in Phytophthora gonapodyides - P. megasperma ITS clade 6, which tend to be high-temperature tolerant and either inbreeding or sterile. Mycol. Res. 2003, 107, 277-290. [CrossRef] [PubMed]

76. Hansen, E.M.; Reeser, P.; Sutton, W.; Brasier, C.M. Redesignation of Phytophthora taxon Pgchlamydo as Phytophthora chlamydospora sp. nov. North Am. Fungi 2015, 10, 1-14. [CrossRef]

77. Hansen, E.; Reeser, P.; Sutton, W. Phytophthora chlamydospora. Forest Phytophth. 2019, 8, 1. [CrossRef]

78. Balci, Y.; Halmschlager, E. Incidence of Phytophthora species in oak forests in Austria and their possible involvement in oak decline. For. Pathol. 2003, 33, 157-174. [CrossRef]

79. Corcobado, T.; Cubera, E.; Pérez-Sierra, A.; Jung, T.; Solla, A. First report of Phytophthora gonapodyides involved in the decline of Quercus ilex in xeric conditions in Spain. New Dis. Rep. 2010, 22, 2044-0588. [CrossRef]

80. Aghighi, S.; Hardy, G.E.S.J.; Scott, J.K.; Burgess, T.I. Phytophthora bilorbang sp. nov., a new species associated with the decline of Rubus anglocandicans (European blackberry) in Western Australia. Eur. J. Plant Pathol. 2012, 133, 841-855. [CrossRef]

81. Luongo, L.; Haegi, A.; Galli, M.; Berti, S.; Vitale, S.; Belisario, A. First report of Phytophthora megasperma causing decline and death on Celtis australis in Italy. Plant Dis. 2015, 99, 155. [CrossRef]

82. Copes, W.E.; Yang, X.; Hong, C. Phytophthora species recovered from irrigation reservoirs in Mississippi and Alabama nurseries and pathogenicity of three new species. Plant Dis. 2015, 99, 1390-1395. [CrossRef] [PubMed]

83. Scanu, B.; Linaldeddu, B.T.; Deidda, A.; Jung, T. Diversity of Phytophthora species from declining Mediterranean maquis vegetation, including two new species, Phytophthora crassamura and P. ornamentata sp. nov. PLoS ONE 2015, 10, e0143234. [CrossRef] [PubMed]

84. Farr, D.F.; Rossman, A.Y. Fungal databases, U.S. National Fungus Collections, ARS, USDA. Available online: https://nt.ars-grin.gov/fungaldatabases/ (accessed on 1 July 2020).

85. Scott, P.; Taylor, P.; Gardner, J.; Puértolas, A.; Panda, P.; Addison, S.; Hood, I.; Burgess, T.; Horner, I.; Williams, N.; et al. Phytophthora aleatoria sp. nov., associated with root and collar damage on Pinus radiata from nurseries and plantations. Australas. Plant Pathol. 2019, 48, 313-321. [CrossRef] 
86. Jung, T.; Burgess, T.I. Re-evaluation of Phytophthora citricola isolates from multiple woody hosts in Europe and North America reveals a new species, Phytophthora plurivora sp. nov. Persoonia 2009, 22, 95. [CrossRef]

87. Bezuidenhout, C.M.; Denman, S.; Kirk, S.A.; Botha, W.J.; Mostert, L.; McLeod, A. Phytophthora taxa associated with cultivated Agathosma, with emphasis on the P. citricola complex and P. capensis sp. nov. Persoonia 2010, 25, 32. [CrossRef]

88. Rytkönen, A.; Lilja, A.; Werres, S.; Sirkiä, S.; Hantula, J. Infectivity, survival and pathology of Finnish strains of Phytophthora plurivora and Ph. pini in Norway spruce. Scand. J. For. Res. 2013, 28, 307-318. [CrossRef]

89. Scanu, B.; Linaldeddu, B.T.; Perez-Sierra, A.; Deidda, A.; Franceschini, A. Phytophthora ilicis as a leaf and stem pathogen of Ilex aquifolium in Mediterranean islands. Phytopathologia Mediterranea 2014, 480-490. [CrossRef]

90. Bertier, L.; Brouwer, H.; de Cock, A.W.A.M.; Cooke, D.E.L.; Olsson, C.H.B.; Höfte, M. The expansion of Phytophthora clade 8b: Three new species associated with winter grown vegetable crops. Persoonia 2013, 31, 63. [CrossRef]

91. Delshad, D.; Mostowfizadeh-Ghalamfarsa, R.; Safaiefarahani, B. Potential host range and the effect of temperature on the pathogenicity of Phytophthora pseudocryptogea and its close relatives. J. Plant Pathol. 2020, 1-11. [CrossRef]

92. Jung, T.; Orlikowski, L.; Henricot, B.; Abad-Campos, P.; Aday, A.G.; Aguín Casal, O.; Bakonyi, J.; Cacciola, S.O.; Cech, T.; Chavarriaga, D.; et al. Widespread Phytophthora infestations in European nurseries put forest, semi-natural and horticultural ecosystems at high risk of Phytophthora diseases. For. Pathol. 2016, 46, 134-163. [CrossRef]

93. Bienapfl, J.C.; Balci, Y. Movement of Phytophthora spp. in Maryland's nursery trade. Plant Dis. 2014, 98, 134-144. [CrossRef] [PubMed]

94. Giordana, G.; Kitzberger, T.; La Manna, L. Anthropogenic factors control the distribution of a southern conifer Phytophthora disease in a peri-urban area of northern Patagonia, Argentina. Forest 2020, 11, 1183. [CrossRef]

95. Cushman, J.H.; Meentemeyer, R.K. Multi-scale patterns of human activity and the incidence of an exotic forest pathogen. J. Ecol. 2008, 96, 766-776. [CrossRef]

96. Dale, A.; Feau, N.; Ponchart, J. Urban activities influence on Phytophthora species diversity in British Columbia, Canada. In Proceedings of the Sudden Oak Death Sixth Science Symposium; General Technical Report GTR-PSW-255; Frankel, S.J., Harrell, K.M., Eds.; U.S. Department of Agriculture, Forest Service, Pacific Southwest Research Station: Albany, CA, USA, 2017; pp. 31-32.

97. Redondo, M.; Boerg, J.; Stenlid, J.; Oliva, J. Functional traits associated with the establishment of introduced Phytophthora spp. in Swedish forests. J. Appl. Ecol. 2018, 55, 1538-1552. [CrossRef]

98. NASA Prediction of Worldwide Energy Resources. Available online: https://power.larc.nasa.gov/ (accessed on 27 June 2020).

99. Tarabini, M.; Gomez, F.; Calderón, M.; La Manna, L. Abiotic factors related to Nothofagus pumilio forest disease in the treeline ecotone. For. Ecol. Manag.. manuscript in preparation.

100. La Manna, L.; Carabelli, F.; Gómez, M.; Matteucci, S.D. Disposición espacial de parches de Austrocedrus chilensis con síntomas de defoliación y mortalidad en el Valle 16 de Octubre (Chubut, Argentina). Bosque 2008, 29, 23-32. [CrossRef]

101. Elliot, M.; Schlenzig, A.; Harris, C.; Meagher, T.; Green, S. An improved method for the qPCR detection of Phytophthora spp. in forest and woodland soils in northern Britain. For. Pathol. 2015, 45, 537-539. [CrossRef]

102. Taccari, L.E.; Vélez, M.L.; Greslebin, A.G. Callus Induction in Austrocedrus Chilensis, a Vulnerable Conifer from Patagonia. Book of Abstracts of the 5th 2.09.02 Working Party Conference: Somatic Embryogenesis and Other Vegetative Propagation Technologies-Clonal Trees in the Bioeconomy Age: Opportunities and Challenges; IUFRO: Coimbra, Portugal, 2018; p. 125.

Publisher's Note: MDPI stays neutral with regard to jurisdictional claims in published maps and institutional affiliations. 